ANL- 7412

Chemical Separations

Processes for Plutonium

and Uranium (TID-4500)

AEC Research and

Development Report

\author{
ARGONNE NATIONAL LABORATORY \\ 9700 South Cass Avenue \\ Argonne, Illinois 60439
}

\title{
LABORATORY INVESTIGATIONS IN SUPPORT OF FLUID-BED FLUORIDE VOLATILITY PROCESSES

\author{
Part XIX. Reaction of Bromine Pentafluoride \\ with Selected Compounds of \\ Uranium and Plutonium
}

by

R. L. Jarry, J. J. Stockbar, and $M$. J. Steindler

Chemical Engineering Division

March 1968

\section{LEGAL NOTICE}

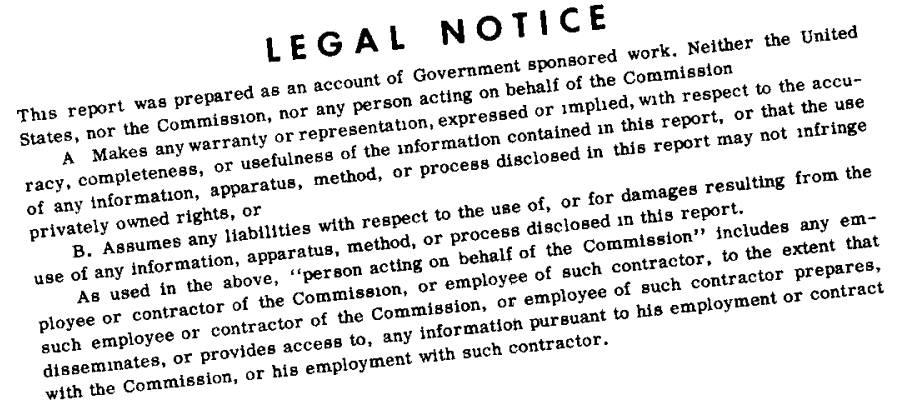

TISTREUTHON OF MIIS DOCUMENG LS UNLIMITER 


\section{DISCLAIMER}

This report was prepared as an account of work sponsored by an agency of the United States Government. Neither the United States Government nor any agency Thereof, nor any of their employees, makes any warranty, express or implied, or assumes any legal liability or responsibility for the accuracy, completeness, or usefulness of any information, apparatus, product, or process disclosed, or represents that its use would not infringe privately owned rights. Reference herein to any specific commercial product, process, or service by trade name, trademark, manufacturer, or otherwise does not necessarily constitute or imply its endorsement, recommendation, or favoring by the United States Government or any agency thereof. The views and opinions of authors expressed herein do not necessarily state or reflect those of the United States Government or any agency thereof. 


\section{DISCLAIMER}

Portions of this document may be illegible in electronic image products. Images are produced from the best available original document. 
Other reports in this series are:

Part I. The Fluorination of Uranium Dioxide-Plutonium Dioxide Solid Solutions (ANL-6742).

Part II. The Properties of Plutonium Hexafluoride (ANL-6753).

Part III. Separation of Gaseous Mixtures of Uranium Hexafluoride and Plutonium Hexafluoride by Thermal Decomposition (ANL-6762).

Part IV. The Fluid-bed Fluorination of $\mathrm{U}_{3} \mathrm{O}_{8}$ (ANL-6763).

Part V. The Radiation Chemistry of Plutonium Hexafluoride (ANL-6812).

Part VI. A. The Absorption Spectrum of Plutonium Hexafluoride;

B. Analysis of Mixtures of Plutonium Hexafluoride and Uranium Hexafluoride by Absorption Spectrometry (ANL-6817).

Part VII. The Decomposition of Gaseous Plutonium Hexafluoride by Alpha Radiation (ANL-7013).

Part VIII. Analysis of an Accidental Multigram Release of Plutonium Hexafluoride in a Glovebox (ANL-7068).

Part IX. The Fluid-bed Fluorination of a Plutonium-containing Simulated Oxidic Nuclear Fuel in a $1 \frac{1}{2}$-inch-diameter Reactor (ANL-7077).

Part X. A Literature Survey on the Properties of Tellurium, Its Oxygen and Fluorine Compounds (ANL-7142).

Part XI. Vapor-Liquid Equilibria in the System Uranium Hexafluoride-Plutonium Hexafluoride (ANL-7186).

Part XII. The Melting-point Diagram for the System Uranium HexafluoridePlutonium Hexafluoride (ANL-7234).

Part XIII. Condensed-phase Equilibria in the System Molybdenum HexafluorideUranium Hexafluoride (ANL-7240).

Part XIV. The Corrosion of Nickel and Nickel Alloys by Fluorine, Uranium Hexafluoride, and Selected Volatile Fission Product Fluorides at $500^{\circ} \mathrm{C}$ (ANL-7241).

Part XV. Estimation of Rates of Thermal Decomposition of Plutonium Hexafluoride in Process Streams (ANL-7347).

Part XVI. The Fluorination of $\mathrm{UO}_{2}-\mathrm{PuO}_{2}-\mathrm{Fis}$ sion-product Oxide Pellets with Fluorine in a 2-inch-diameter Fluid-bed Reactor (ANL-7372).

Part XVII. Fluorination of Neptunium(IV) Fluoride and Neptunium(IV) Oxide (ANL-7385) (to be published).

Part XVIII. Neutron Counting as an Analytical Method for Plutonium Fluorides (ANL-7402) (to be published). 


\section{TABLE OF CONTENTS}

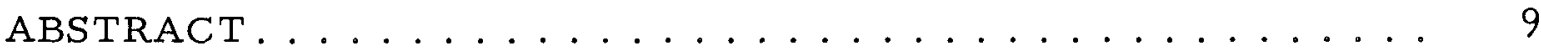

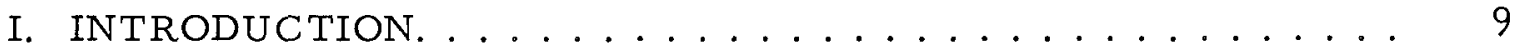

II. EXPERIMENTAL PROCEDURE ............... 11

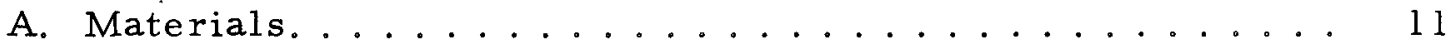

1. Uranium Compounds .................. l l

2. Plutonium Dioxide.................. 11

3. Bromine Pentafluoride............... 11

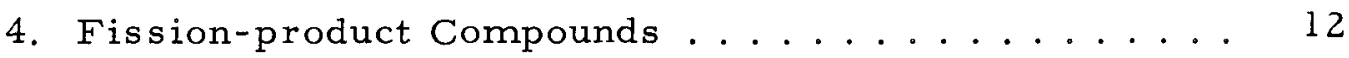

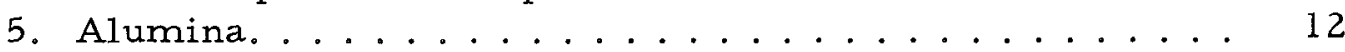

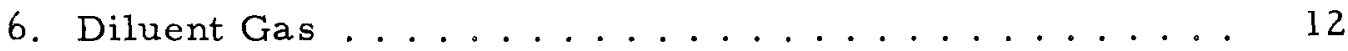

7. Zircaloy Decladding Product............ 12

8. Stainless Steel Decladding Product............ 13

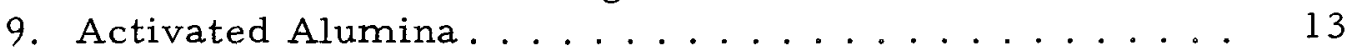

10. Soda Lime ..................... 13

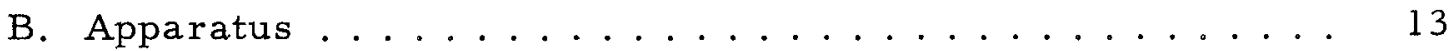

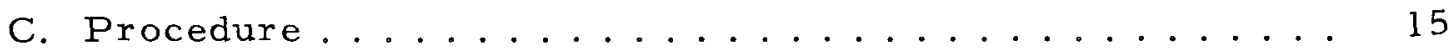

1. Boat Reactor ................... 15

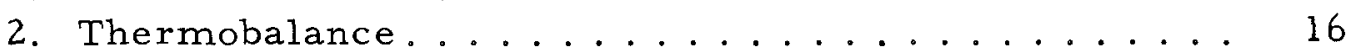

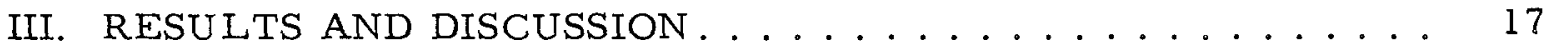

A. Reaction of $\mathrm{BrF}_{5}$ with Simulated Fluid-bed Solid

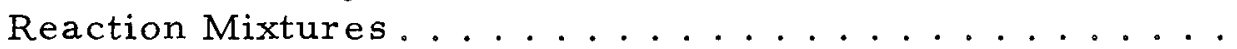

1. Reaction of $\mathrm{BrF}_{5}$ with Mixtures of Alumina, $\mathrm{UO}_{2} \mathrm{~F}_{2}$, $\mathrm{UF}_{4}$, and Fission-product Oxides .......... 17

2. Fluorination of $\mathrm{U}_{3} \mathrm{O}_{8}$-Alumina-Fission-product

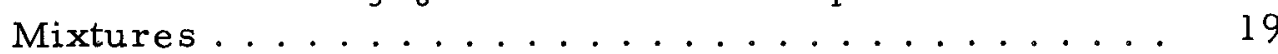

3. Fluorination of $\mathrm{U}_{3} \mathrm{O}_{8}-\mathrm{PuO}_{2}-$ Alumina-Fis sion-product Mixtures .................... 20

4. Comparison of Reactivity of $\mathrm{BrF}_{5}$ and Fluorine. . . . 22

B. Kinetic Studies ....................... 22

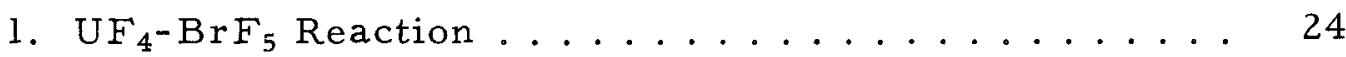

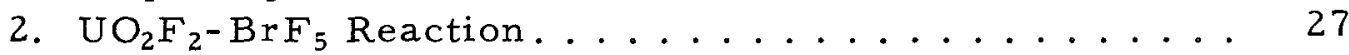

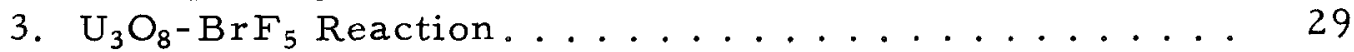

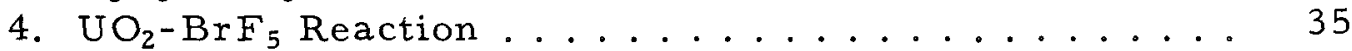


$\underline{\text { Page }}$

5. $\mathrm{UO}_{3}-\mathrm{BrF}_{5}$ Reaction ....................... 37

6. Mechanisms of the $\mathrm{UO}_{2}-\mathrm{BrF}_{5}$ and $\mathrm{UO}_{3}-\mathrm{BrF}_{5}$

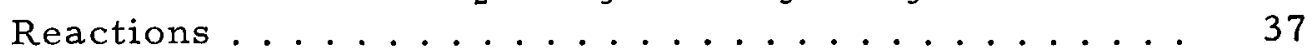

C. Disposal of $\mathrm{BrF}_{5} \ldots \ldots \ldots \ldots \ldots$

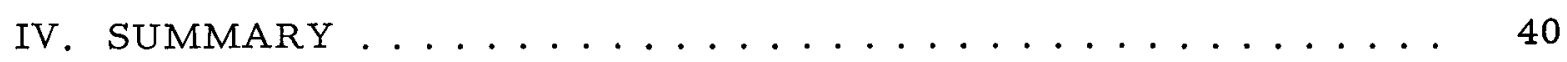

A. Reactions with Simulated Fluid-bed Charges . . . . . . . 40

B. Kinetics of the Reaction of $\mathrm{BrF}_{5}$ with $\mathrm{UF}_{4}, \mathrm{UO}_{2} \mathrm{~F}_{2}, \mathrm{U}_{3} \mathrm{O}_{8}$, $\mathrm{UO}_{2}$, and $\mathrm{UO}_{3} \ldots \ldots \ldots . \ldots \ldots 40 . \ldots \ldots$

C. Disposal of $\mathrm{BrF}_{5} \ldots \ldots \ldots \ldots 1$

ACKNOW LEDGMENTS . . . . . . . . . . . . . . . . . . 41

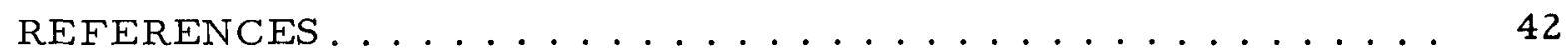




\section{LIST OF FIGURES}

No.

$\underline{\text { Title }}$

$\underline{\text { Page }}$

1. Boat-reactor System, Schematic Diagram ...........

2. Sartorius Thermobalance System ............... 14

3. Thermobalance Reactor Tube, Schematic Diagram....... 15

4. Variation of Rate Constants for Reaction of Mixtures of $\mathrm{UF}_{4}$ and $\mathrm{UO}_{2} \mathrm{~F}_{2}$ with $\mathrm{BrF}_{5}$ over Range $175-250^{\circ} \mathrm{C} \ldots \ldots$

5. Temperature Dependence of Rate Constant for $\mathrm{UF}_{4}-\mathrm{BrF}_{5}$

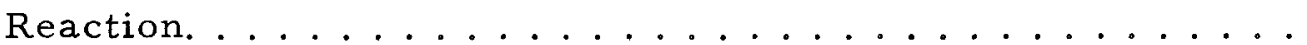

6. Effect of $B r F_{5}$ Partial Pressure on Rate Constant for $U F_{4}-B_{r} F_{5}$

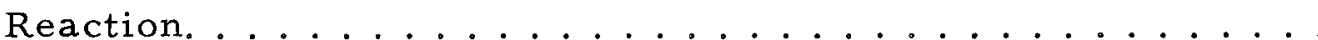

7. Effect of $\mathrm{BrF}_{5}$ Partial Pressure on Conversion of Uranium to $\mathrm{UF}_{6}$ for $\mathrm{UO}_{2} \mathrm{~F}_{2}-\mathrm{BrF}_{5}$ Reaction at $250^{\circ} \mathrm{C} \ldots \ldots \ldots$

8. Temperature Dependence of Rate Constant for $\mathrm{UO}_{2} \mathrm{~F}_{2}-\mathrm{BrF}_{5}$

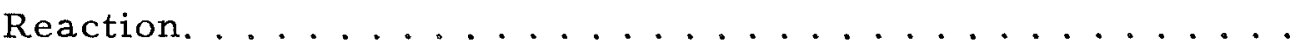

9. Effect of $\mathrm{BrF}_{5}$ Partial Pressure on Rate Constant for

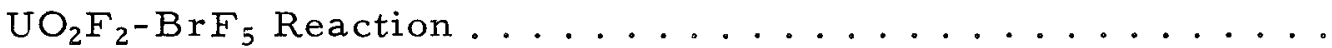

10. Temperature Dependence of Rate Constant for $\mathrm{U}_{3} \mathrm{O}_{8}-\mathrm{BrF}_{5}$ Reaction

11. Effect of $\mathrm{BrF}_{5}$ Partial Pressure on Rate Constant for

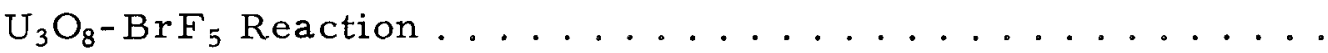

12. Plots of $(1-F)^{1 / 3}$ vs. Reaction Time, $t$, for Range

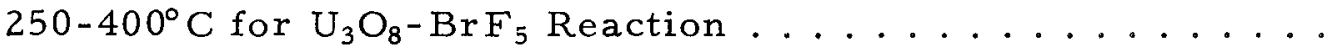

13. Fraction of Solid Residue Present as $\mathrm{U}_{3} \mathrm{O}_{8}$ and $\mathrm{UO}_{2} \mathrm{~F}_{2}$ for

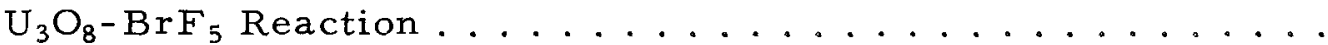

14. Distribution of Original Uranium as $\mathrm{UO}_{2} \mathrm{~F}_{2}$ and $\mathrm{U}_{3} \mathrm{O}_{8}$ in Reaction Residues and as Volatilized $\mathrm{UF}_{6}$ for $\mathrm{U}_{3} \mathrm{O}_{8}-\mathrm{BrF}_{5}$ Reaction

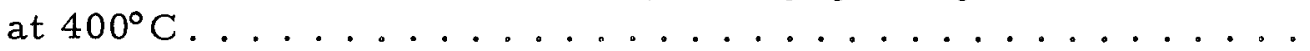

15. Distribution of Original Uranium as $\mathrm{UO}_{2} \mathrm{~F}_{2}$ and $\mathrm{U}_{3} \mathrm{O}_{8}$ in Reaction Residues and as Volatilized $\mathrm{UF}_{6}$ for $\mathrm{U}_{3} \mathrm{O}_{8}-\mathrm{BrF}_{5}$ Reaction at $250^{\circ} \mathrm{C} \ldots \ldots \ldots \ldots \ldots$ 


\section{LIST OF FIGURES}

No.

Title

$\underline{\text { Page }}$

16. Temperature Dependence of Rate Constants for $\mathrm{UO}_{2}-\mathrm{BrF}_{5}$

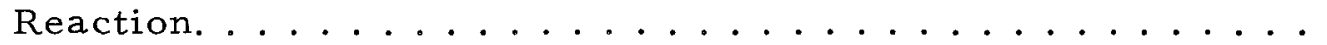

17. Temperature Dependence of Rate Constants for $\mathrm{UO}_{3}-\mathrm{BrF}_{5}$

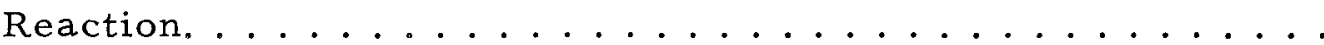

18. Comparison of Reactions of $\mathrm{U}_{3} \mathrm{O}_{8}, \mathrm{UO}_{3}$, and $\mathrm{UO}_{2}$ with $\mathrm{BrF}_{5}$ at $300^{\circ} \mathrm{C} \ldots \ldots \ldots \ldots \ldots$

19. Temperature Dependence of Rate Constants for Reactions of $\mathrm{BrF}_{5}$ with Uranium Compounds at a $\mathrm{BrF}_{5}$ Partial Pressure

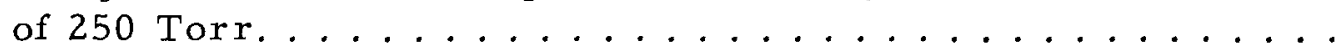




\section{LIST OF TABLES}

No.

Title

$\underline{\text { Page }}$

I. Specifications of Uranium Compounds ............ 11

II. Composition of Fission-product Mixture VI. . . . . . . . . 12

III. Experimental Conditions and Results for Fluorination of $\mathrm{Al}_{2} \mathrm{O}_{3}-\mathrm{UO}_{2} \mathrm{~F}_{2}-\mathrm{UF}_{4}-\mathrm{Fis}$ ion-product Mixtures Using $\mathrm{BrF}_{5} \ldots$. .

IV. Effect of Temperature and Presence of Stainless Steel or Zircaloy Decladding Product on Reaction between BrF $F_{5}$ and Uranium, Alumina, and Fission-product Mixtures......

V. Reaction Rate Constants, $\mathrm{k}^{\prime}$, for Reactions Using $\mathrm{BrF}_{5}$ or

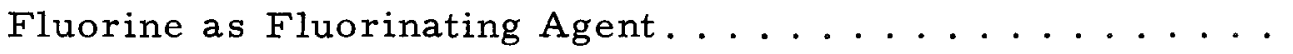

VI. Reaction Rate Constants, $\mathrm{k}^{\prime}$, for $\mathrm{UF}_{4}-\mathrm{BrF}_{5}$ Reaction . . . . . 24

VII. Reaction Rate Constants, $k^{\prime}$, for $\mathrm{UO}_{2} \mathrm{~F}_{2}-\mathrm{BrF} \mathrm{F}_{5}$ Reaction .... 28

VIII. Reaction Rate Constants, $\mathrm{k}^{\prime}$, for $\mathrm{U}_{3} \mathrm{O}_{8}-\mathrm{Br} \mathrm{F}_{5}$ Reaction ..... 30

IX. Effect of Linear Velocity of Gas Phase on Reaction Rate

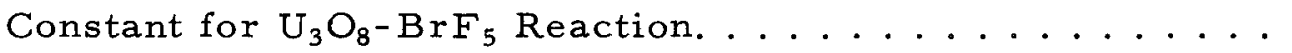

X. Reaction Rate Constants, $\mathrm{k}^{\prime}$, for $\mathrm{UO}_{2}-\mathrm{BrF}_{5}$ Reaction..... 35

XI. Effect of $\mathrm{BrF}_{5}$ Partial Pressure for Reactions with $\mathrm{UO}_{2}$ and $\mathrm{UO}_{3} \ldots \ldots \ldots \ldots$

XII. Reaction Rate Constants, $\mathrm{k}^{\prime}$, for $\mathrm{UO}_{3}-\mathrm{BrF} \mathrm{F}_{5}$ Reaction......

XIII. Constants for Rate Equations for Reactions of $\mathrm{BrF}_{5}$ with Uranium Compounds . . . . . . . . . . . . . . . 


\title{
LABORATORY INVESTIGATIONS IN SUPPORT OF \\ FLUID-BED FLUORIDE VOLATILITY PROCESSES

\author{
Part XIX. Reaction of Bromine Pentafluoride \\ with Selected Compounds of \\ Uranium and Plutonium
}

by

\author{
R. L。Jarry。 J。J。Stockbar, \\ and $M_{0} J$ 。 Steindler
}

\begin{abstract}
The use of $\mathrm{BrF}_{5}$ to selectively remove uranium from mixtures with plutonium has been studied. The results show that uranium in mixtures with alumina, plutonium dioxide, and fission-product compounds can easily be converted to $\mathrm{UF}_{6}$ at $350^{\circ} \mathrm{C}$ or lower using $20 \% \mathrm{BrF}_{5}$ in nitrogen as the fluorinating gas while converting the plutonium only to the nonvolatile $\mathrm{PuF}_{4}$. The presence of $\mathrm{Zircaloy}$ or stainless steel decladding product did not hinder the removal of uranium. Plutonium could be satisfactorily converted to $\mathrm{PuF}_{6}$ by a s econd fluorination step at $500-550^{\circ} \mathrm{C}$ using elemental fluorine.

The kinetics of the reaction of $\mathrm{BrF}_{5}$ with $\mathrm{UF}_{4}, \mathrm{UO}_{2} \mathrm{~F}_{2}$, $\mathrm{U}_{3} \mathrm{O}_{8}, \mathrm{UO}_{2}$, and $\mathrm{UO}_{3}$ were determined; and activation energies of $16.9,8.3,9.2,7.5$, and $7.7 \mathrm{kcal} / \mathrm{mole}$, respectively, were derived. Values of the coefficient $\mathrm{n}$ for the pressure term in the equation $k^{\prime}=A e^{-E / R T} P^{n}$ of $0.38,0.71,0.90,0.84$, and 1.05 were derived for the reactions with $\mathrm{UF}_{4}, \mathrm{UO}_{2} \mathrm{~F}_{2}$, $\mathrm{U}_{3} \mathrm{O}_{8}, \mathrm{UO}_{2}$, and $\mathrm{UO}_{3}$, respectively。
\end{abstract}

\section{INTRODUCTION}

The fluid-bed fluoride-volatility process (FBFVP) is designed to recover uranium and plutonium from low-enrichment, stainless steel or Zircaloy-clad, uranium dioxide fuels. The ANL reference flowsheet ${ }^{1}$ involves the following steps: (1) removal of Zircaloy cladding by reacting it with gaseous $\mathrm{HCl}$ to form volatile $\mathrm{ZrCl}_{4}$, with subsequent conversion of $\mathrm{ZrCl}_{4}$ to the solid oxide in a second vessel by reaction with steam, or removal of the stainless steel cladding by reacting it with an HF-oxygen mixture to convert the cladding to a mixture of the solid oxides of its constituent elements; (2) fluorination of the uranium and plutonium species to the hexafluorides, $\mathrm{UF}_{6}$ and $\mathrm{PuF}_{6}$ (3) separation of the $\mathrm{PuF}_{6}$ from $\mathrm{UF}_{6}$ by thermal 
decomposition of the $\mathrm{PuF}_{6}$ to solid $\mathrm{PuF}_{4}$; and (4) decontamination of the $\mathrm{UF}_{6}$ by fractional distillation, aided by adsorption techniques. Considerable advantage may be gained, however, if uranium and plutonium can be separated by volatilizing separate $\mathrm{UF}_{6}$ and $\mathrm{PuF}_{6}$ stream from the fluorination reactor.

One method which may be applied to achieve such a separation is the selective fluorination of uranium (including most of the fission products that form volatile fluorides) without removing the plutonium from the fluorination reactor. For example, the reactions of $\mathrm{BrF}_{3}$ (Ref. 2) and $\mathrm{SF}_{4}$ (Ref. 3) with uranium and plutonium compounds generally result in the conversion of the uranium compounds to $\mathrm{UF}_{6}$ and the conversion of the plutonium compounds only to nonvolatile $\mathrm{PuF}_{4}$. Of the various reagents that could be useful for selective fluorination, bromine penetafluoride $\left(\mathrm{BrF}_{5}\right)$ appears to hold considerable promise. Selective fluorination is expected to have the following potential advantages:

1. Shorter overall plutonium fluorination time would be possible, if plutonium (as $\mathrm{PuF}_{4}$ ) from several batches of feed could be allowed to accumulate in the fluid bed before recovery by reaction with fluorine.

2. Conversion of $\mathrm{PuF}_{6}$ to $\mathrm{PuF}_{4}$ (by thermal decomposition or chemical reduction) would be simplified if $\mathrm{UF}_{6}$ and fission products were absent.

3. Purification and decontamination of $\mathrm{UF}_{6}$ would be simplified if $\mathrm{PuF}_{6}$ were absent.

4. Collection of $\mathrm{UF}_{6}$ in a liquid mixture with $\mathrm{BrF}_{5}$ may be more efficient than when $\mathrm{UF}_{6}$, formed by reaction of uranium with fluorine, must be condensed from a gas phase containing fluorine and nitrogen.

An experimental program has been conducted to evaluate the selectivity of $\mathrm{BrF}_{5}$ as a fluorinating agent for uranium in mixtures with plutonium compounds. The experimental program involved study of the reaction of $\mathrm{BrF}_{5}$ with simulated fluid-bed solid reaction mixtures containing uranium compounds $\left(\mathrm{UO}_{2} \mathrm{~F}_{2}, \mathrm{UF}_{4}\right.$, and $\left.\mathrm{U}_{3} \mathrm{O}_{8}\right)$, plutonium compounds, alumina, and nonradioactive fission-product element compounds. These experiments were performed to determine the optimum reaction conditions for the removal of $>99 \%$ of the uranium as volatile $\mathrm{UF}_{6}$. In some experiments, stainless steel decladding product or Zircaloy decladding product was added to the solid mixtures to determine the effect of this addition on uranium removal.

Plutonium was added, as $\mathrm{PuO}_{2}$, to solid mixtures containing $\mathrm{U}_{3} \mathrm{O}_{8}$ to determine if any of the plutonium would be volatilized during the reaction with $\mathrm{BrF}_{5}$. The residue remaining after $\mathrm{BrF}_{5}$ fluorination was subsequently treated with elemental fluorine to determine the extent of conversion of the plutonium to $\mathrm{PuF}_{6}$. 
Finally, the kinetics of the reaction of $\mathrm{BrF}_{5}$ with $\mathrm{UF}_{4}, \mathrm{UO}_{2} \mathrm{~F}_{2}$, $\mathrm{U}_{3} \mathrm{O}_{8}, \mathrm{UO}_{2}$, and $\mathrm{UO}_{3}$ were determined. Equations representing the temperature and $\mathrm{BrF}_{5}$ concentration dependences of the several reactions and the values of the activation energies of the reaction were derived from these kinetic data.

\section{EXPERIMENTAL PROCEDURE}

\section{A. Materials}

\section{Uranium Compounds}

The specifications for the uranium compounds used in this study are listed in Table $I$.

TABLE I. Specifications of Uranium Compounds

\begin{tabular}{|c|c|c|c|c|c|c|c|c|}
\hline \multirow[b]{3}{*}{ Compound } & \multicolumn{6}{|c|}{ Analytical Results, $\%$} & \multirow{3}{*}{$\begin{array}{c}\text { Average } \\
\text { Particle } \\
\text { Diameter, } \mu\end{array}$} & \multirow{3}{*}{$\begin{array}{c}\text { Surfac } \\
\text { Area, } \\
\mathrm{m}^{2} / \mathrm{g}\end{array}$} \\
\hline & \multicolumn{3}{|c|}{ Found } & \multicolumn{3}{|c|}{ Theoretical } & & \\
\hline & $\mathrm{U}$ & $\mathrm{O}$ & $F$ & $\mathrm{U}$ & 0 & $F$ & & \\
\hline $\mathrm{U}_{3} \mathrm{O}_{8}$ & 84.7 & 15.2 & - & 84.8 & 15.2 & - & 10 & 0.23 \\
\hline $\mathrm{ANL} \mathrm{UO}_{2}$ & 88.3 & 12.0 & - & 88.2 & 11.9 & - & 81 & 0.46 \\
\hline $\mathrm{NUMEC} \mathrm{UO}_{2}$ & 88.1 & 12.0 & - & 88.2 & 11.9 & - & 81 & 0.04 \\
\hline $\mathrm{UO}_{3}$ & 82.7 & 16.7 & - & 83.2 & 16.8 & - & 81 & 0.67 \\
\hline $\mathrm{UF}_{4}$ & 75.6 & - & 23.8 & 75.8 & - & 24.2 & 84 & 0.30 \\
\hline $\mathrm{UO}_{2} \mathrm{~F}_{2}$ & 77.3 & 12.1 & $\mathrm{a}$ & 77.3 & 10.4 & 12.3 & 55 & 12.2 \\
\hline
\end{tabular}

a Not determined.

\section{Plutonium Dioxide}

The plutonium dioxide contained $88.0 \%$ plutonium $(88.2 \%$ theoretical) and had a specific activity of $8.47 \times 10^{7}$ counts $/ \mathrm{min}-\mathrm{mg}$ of plutonium.

\section{Bromine Pentafluoride}

The $\mathrm{BrF}_{5}$ was obtained from the Matheson Co. and was stated to be of a purity of at least $98 \%$. A check of the vapor pressure at $0^{\circ} \mathrm{C}$ and at room temperature did not show evidence of contamination by volatile substances. An infrared scan of the $\mathrm{BrF}_{5}$ was made. The very strong peak at $644 \mathrm{~cm}^{-1}$ and the weak peak at $580 \mathrm{~cm}^{-1}$ reported by Stein ${ }^{4}$ were found; peaks at 1192 and $1226 \mathrm{~cm}^{-1}$ were noted, but not in the strength reported. Inspection of the scan did not show the very strong peak at $613 \mathrm{~cm}^{-1}$ for $\mathrm{BrF}_{3}$ reported by Claassen et al. ${ }^{5}$ 


\section{Fission-product Compounds}

The fission-product mixture, designated Fission Product Mixture VI, contained the following compounds: $\mathrm{Y}_{2} \mathrm{O}_{3}, \mathrm{ZrO}_{2}, \mathrm{BaO}, \mathrm{La}_{2} \mathrm{O}_{3}$, $\mathrm{CeO}_{2}, \mathrm{Pr}_{6} \mathrm{O}_{11}, \mathrm{Nd}_{2} \mathrm{O}_{3}, \mathrm{Sm}_{2} \mathrm{O}_{3}, \mathrm{Eu}_{2} \mathrm{O}_{3}, \mathrm{Gd}_{2} \mathrm{O}_{3}, \mathrm{MoO}_{3}, \mathrm{SrF} \mathrm{F}_{2}, \mathrm{CsF}, \mathrm{Nb}_{2} \mathrm{O}_{5}$, and $\mathrm{RuO}_{2}$. The concentrations of the compounds, which are the amounts calculated to be present in partially spent Dresden-type fuel elements of specified burnup and cooling period, are listed in Table II. All compounds used to make up the fission-product mixture had purities of $99 \%$ or greater.

TABLE II. Composition of Fission-product Mixture VI

\begin{tabular}{lc|cc}
\hline $\begin{array}{c}\text { Fission } \\
\text { Product }\end{array}$ & $\begin{array}{c}\text { Weight, g, } \\
\text { of Compound } \\
\text { per } 100 \mathrm{~g} \\
\text { of Uranium }\end{array}$ & $\begin{array}{c}\text { Fission } \\
\text { Product } \\
\text { Compound }\end{array}$ & $\begin{array}{c}\text { Weight, g, } \\
\text { of Compound }\end{array}$ \\
$\begin{array}{c}\text { per } 100 \mathrm{~g} \\
\mathrm{Y}_{2} \mathrm{O}_{3}\end{array}$ & 26.4 & $\mathrm{Eu}_{2} \mathrm{O}_{3}$ & 1.99 \\
$\mathrm{ZrO}_{2}$ & 209.1 & $\mathrm{Gd}_{2} \mathrm{O}_{3}$ & 0.46 \\
$\mathrm{BaO}$ & 66.5 & $\mathrm{MoO}_{3}$ & 214.8 \\
$\mathrm{La}_{2} \mathrm{O}_{3}$ & 57.0 & $\mathrm{SrF}_{2}$ & 47.2 \\
$\mathrm{CeO}_{2}$ & 108.3 & $\mathrm{CsF}$ & 149.7 \\
$\mathrm{Pr}_{6} \mathrm{O}_{11}$ & 50.2 & $\mathrm{Nb}_{2} \mathrm{O}_{5}$ & 0.23 \\
$\mathrm{Nd}_{2} \mathrm{O}_{3}$ & 198.2 & $\mathrm{RuO}_{2}$ & 106.2 \\
$\mathrm{Sm}_{2} \mathrm{O}_{3}$ & 45.6 & & \\
\hline
\end{tabular}

\footnotetext{
${ }^{a}$ Based on fission-product distribution calculated for Dresden-type low-enrichment $\mathrm{UO}_{2}$ fuel, 10,000-MWd/ton burnup, 4-yr exposure, 30-day cooled.
}

\section{Alumina}

Alcoa T-61 tabular alumina was used. This material had a median particle size of $150 \mu$ and a particle-size range of $80-250 \mu$.

\section{Diluent Gas}

Nitrogen was used as the diluting medium. The source of the nitrogen was the house supply, and the gas was passed through a bed of Linde Type $4 \mathrm{~A}$ Molecular Sieve to remove water prior to use.

\section{Zircaloy Decladding Product}

The $\mathrm{Zircaloy}$ decladding product was produced by $\mathrm{HF}-\mathrm{O}_{2}$ reaction with Zircaloy-clad $\mathrm{UO}_{2}$ pellets. X-ray analysis indicated that the principal component was $\mathrm{ZrF}_{4}$. The decladding product was ground, and the $-200 \mathrm{mesh}$ fraction was used. The uranium content of the decladding product was determined to be $0.3 \mathrm{w} / \mathrm{o}$. 
8. Stainless Steel Decladding Product

The stainless steel decladding product was produced by $\mathrm{HF}-\mathrm{O}_{2}$ reaction with Type 304 stainless steel. The decladding product contained $47.6 \%$ iron and $12.8 \%$ chromium as determined by chemical analysis. The material was ground, and the -200 mesh fraction was used in the experiments.

\section{Activated Alumina}

Grade F-1, 8-14 mesh, activated alumina produced by Alcoa Chemicals was used. This material had the following specifications: $\mathrm{Al}_{2} \mathrm{O}_{3}$, $92.00 \%$; loss on ignition, 7.00\%; $\mathrm{Na}_{2} \mathrm{O},<0.08 \% ; \mathrm{SiO}_{2},<0.10 \% ; \mathrm{Fe}_{2} \mathrm{O}_{3},<0.10 \%$; and $\mathrm{TiO}_{2},<0.02 \%$.

\section{Soda Lime}

Soda lime is a proprietary chemical and is generally described as an intimate mixture of $\mathrm{NaOH}$ and slaked lime. The soda lime used in this work was Mallinckrodt AR, 4-8 mesh, specified to contain no more than $1 \%$ fines with a loss on drying of $7 \%$.

\section{B. Apparatus}

Two experimental systems were used in this work; one was a conventional boat reactor, and the other was a thermobalance. Associated with each system were a gas-metering manifold and a general-purpose manifold to which a system of cold traps and vacuum services was attached. The manifolds were constructed of nickel tubing and fittings. The valves used were Hoke 413 Series Monel with nickel diaphragms.

The boat-reactor system is shown in Fig. 1. The horizontal tubular reactor was constructed from a 1 -ft length of 2 -in. nominal-size nickel

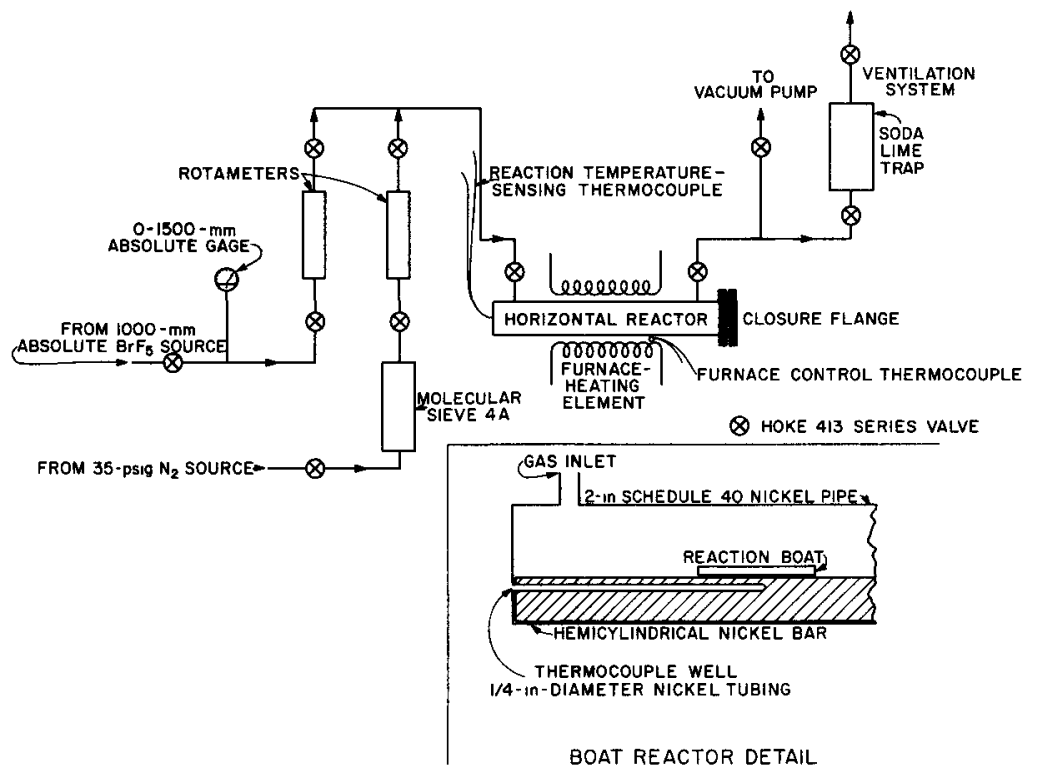

Fig. 1

Boat-reactor System, Schematic Diagram

BOAT REACTOR DETAIL 
pipe flanged at one end. A hemicylindrical nickel bar, with a cross section half that of the reactor, was placed in the reactor to act as a support for the nickel reaction boat and to distribute heat evenly to the bottom of the boat. A nickel boat (4 in. long, $1 \frac{3}{8}$ in. wide, and $3 / 16$ in. deep) contained the solid reactants. The temperature of the boat was sensed by a ChromelAlumel thermocouple placed in a well in the bar at the midpoint of the boat and approximately $1 / 16$ in. from the top surface of the bar.

The Sartorious thermobalance used in this work was previously described by Johnson and Fischer. ${ }^{6}$ The experimental setup is shown in Fig. 2, and a schematic diagram of the reactor tube is shown in Fig. 3. Briefly, the thermobalance consists of a vertical tubular reactor $1 \frac{1}{2}$ in. in diameter and 20 in. long, and a Sartorious Rapid 200 analytical balance equipped with an optical-electronic weight-sensing system and a remote-recording output. The sample of the solid reactant was placed on a nickel sample pan, about $3 / 4$ in. in diameter, which was suspended below the balance pan by a Monel chain that hung through an aperture in the top of the reactor. The sample pan was positioned at about the midpoint of the heated portion of the tubular reactor. A Chromel-Alumel thermocouple in a nickel sheath, placed about $1 / 8$ in. below the sample pan, sensed the reaction temperature.

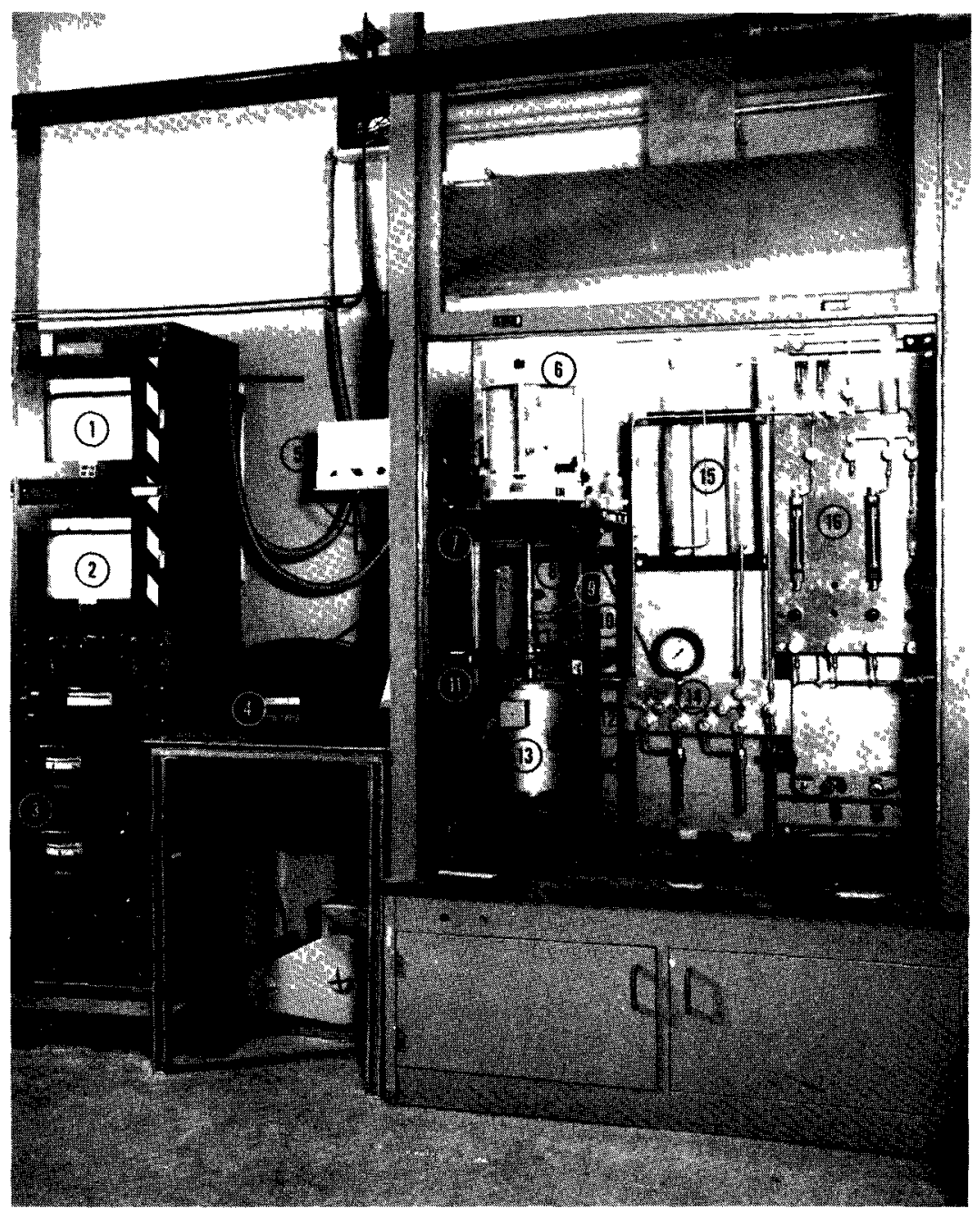

Fig. 2

Sartorious Thermobalance System

\section{LEGEND}

1. Weight-change Recorder

2. Temperature Recorder

3. Temperature-control Console

4. Potentiometer

5. Electronics for Sartorious Balance

6. Sartorious Rapid 200 Analytical Balance

7. Chain Suspension for Sample Pan

8. Chimney

9. Nitrogen Bleed Line

10. Gas Outlet Line

11. Reactor

12. $\mathrm{BrF}_{5}-$ N1trogen Inlet Line

13. Furnace

14. General-purpose Manifold

15. Disposal Towers (Soda Lime, Activated Alumina)

16. Gas-meterıng Manifold 


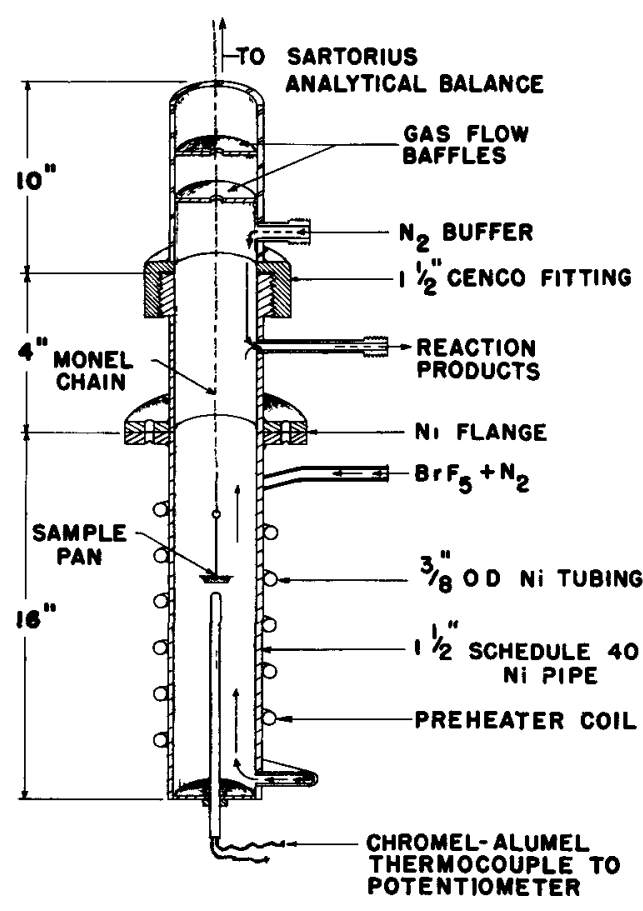

108-9969 Rev. 1

Fig. 3. Thermobalance Reactor Tube, Schematic Diagram

The top of the reactor was maintained at a pressure slightly less than the inlet pressure of the reactor by pumping on the gas outlet line. The fluorinating gas, a mixture of $\mathrm{BrF}_{5}$ and nitrogen, passed through a preheater, consisting of a section of 3/8-in.-diam nickel tubing coiled around the outside of the reactor tube, before entering the bottom of the reactor. A nitrogen bleed flow was brought into the reactor just above the gas outlet line to prevent any reactive gas from escaping through the open top of the reactor. The reagent gases and products were drawn off through the outlet line and passed through a trap containing soda lime. Soda lime at $100^{\circ} \mathrm{C}$ was a satisfactory reactant for converting $\mathrm{BrF}_{5}$ and $\mathrm{UF}_{6}$ to nonvolatile solids.

The gas-metering manifold contained three rotameters for metering fluorine, nitrogen, and $\mathrm{BrF}_{5}$. The nitrogen flowmeter was a conventional glass rotameter; the flowmeters for fluorine and $\mathrm{BrF}_{5}$ were constructed of Kel-F.* Bromine pentafluoride was supplied to the flowmeter at an absolute pressure of $900 \mathrm{~mm} \mathrm{Hg}$ from a liquid storage vessel heated to about $50^{\circ} \mathrm{C}$. The tubing between the storage vessel and the flowmeter, as well as the flowmeter itself, were heated to about $70^{\circ} \mathrm{C}$ to prevent condensation of $\mathrm{BrF}_{5}$ (the boiling point of $\mathrm{BrF} \mathrm{F}_{5}$ is $40.7^{\circ} \mathrm{C}$ ). ${ }^{7}$ The $\mathrm{BrF}_{5}$-nitrogen inlet line from the flowmeter to the reactor and the reactionproduct line from the reactor to a general-purpose manifold were heated to $60-70^{\circ} \mathrm{C}$ to prevent condensation of $\mathrm{BrF}_{5}, \mathrm{Br}_{2}$ (reaction product), and $\mathrm{UF}_{6}$.

The concentration of $\mathrm{BrF}_{3}$ in the $\mathrm{BrF}_{5}$ reagent was not known, but was thought to be of the order of $<2 \mathrm{~m} / \mathrm{o}$. According to the liquid-vapor equilibria data of $\mathrm{Long}^{8}$ for the $\mathrm{BrF}_{3}-\mathrm{BrF}_{5}$ system at $50^{\circ} \mathrm{C}$ and a pressure of 1000 Tor $r$, the vapor phase in equilibrium with the liquid would contain $99 \mathrm{~m} / 0 \mathrm{BrF}_{5}$, even if the liquid phase contained as much as $15 \mathrm{~m} / \mathrm{o} \mathrm{BrF} \mathrm{F}_{3}$ as an impurity.

\section{Procedure}

\section{Boat Reactor}

A weighed sample of solid reactant was carefully placed in the reaction boat to form a uniform layer of material in the boat. The boat

*A polymer of chlorotrifluorethylene. The flowmeter is manufactured by Brooks Instrument Division of Emerson Electric, Hatfield, $\mathrm{Pa}$. 
was then placed in the reactor, and the reactor was closed and then evacuated for leak-testing. A flow of about $200 \mathrm{ml} / \mathrm{min}$ of nitrogen was then started through the reactor, and the heating started. When the system reached the specified reaction temperature, flow of $\mathrm{BrF}_{5}$ was started. The exit gases from the reactor were passed through a trap containing soda lime to remove bromine fluorides and $\mathrm{UF}_{6}$ before exhausting to the ventilation system. After the reaction was completed, the $\mathrm{BrF}_{5}$ flow was stopped and the reactor was cooled to room temperature under an atmosphere of flowing nitrogen. During this period, the $\mathrm{BrF}_{5}$ container was cooled, the material in the feed lines was recondensed, and the $\mathrm{BrF}_{5}$ container was weighed to determine the quantity of $\mathrm{BrF}_{5}$ used in the reaction. The reaction boat was removed from the reactor and weighed to determine the weight loss due to the reaction. For experiments in which pure $\mathrm{UO}_{2} \mathrm{~F}_{2}$ or pure $\mathrm{UF}_{4}$ was fluorinated, the weight loss was sufficient for calculation of the extent of reaction. For the experiments using alumina-uranium compound mixtures, the residue was ground to ensure homogeneous sampling, and a sample was analyzed for uranium to determine the extent of reaction.

\section{Thermobalance}

In the thermobalance experiments, the powdered sample (about $300 \mathrm{mg}$ ) was weighed in the sample pan and placed in the reactor; then nitrogen flow was started. After the reaction temperature was reached, the $\mathrm{BrF}_{5}$ flow was started. The reaction continued for $60 \mathrm{~min}$ or, at the higher temperatures used, for a shorter time. The recorded weight change of the loaded sample pan and the reaction time were used to determine the fraction of uranium converted to $\mathrm{UF}_{6}$ during any increment of reaction time. 


\section{RESULTS AND DISCUSSION}

A. Reaction of $\mathrm{BrF}_{5}$ with Simulated Fluid-bed Solid Reaction Mixtures

Experiments were performed using solid reaction mixtures simulating those used in fluid-bed experiments. Beside uranium compounds, these solid mixtures contained alumina, a mixture of nonradioactive fission-product element oxides and fluorides, and, in some experiments, the decladding product resulting from the reaction of $\mathrm{HF}$-oxygen mixtures with Zircaloy or stainless steel. The uranium compounds used were mixtures of $\mathrm{UO}_{2} \mathrm{~F}_{2}$ and $\mathrm{UF}_{4}$, simulating the product of the reaction of $\mathrm{UO}_{2}$ pellets with an $\mathrm{HF}-\mathrm{O}_{2}$ mixture; or $\mathrm{U}_{3} \mathrm{O}_{8}$, simulating the product of the pulverization of $\mathrm{UO}_{2}$ pellets by reaction with oxygen. Finally, experiments were performed in which $\mathrm{PuO}_{2}$ was added to the solid reaction mixture to affirm that reaction with $\mathrm{BrF}_{5}$ would not produce the volatile $\mathrm{PuF}_{6}$.

\section{Reaction of $\mathrm{BrF}_{5}$ with Mixtures of Alumina, $\mathrm{UO}_{2} \mathrm{~F}_{2}, \mathrm{UF}_{4}$, and} Fission-product Oxides

A series of experiments was performed using a solid reaction mixture simulating those used in fluid-bed experiments. The reaction mixtures contained $10 \mathrm{~g}$ of T-61 alumina (48-100 mesh, nominal) and $0.07 \mathrm{~g}$ of fission-product mixture VI (the composition of which is listed in Table II). The alumina-to-uranium weight ratio in these solid mixtures was $2: 1$, and the $\mathrm{UO}_{2} \mathrm{~F}_{2}$-to-UF $\mathrm{U}_{4}$ weight ratio was also $2: 1$. The experiments were performed using a flow rate of $\mathrm{BrF}_{5}$ of about $0.5 \mathrm{~g} / \mathrm{min}$ in a gas phase containing $26 \mathrm{v} / \mathrm{o} \mathrm{BrF}_{5}$ and $74 \mathrm{v} / \mathrm{o}$ nitrogen. The total flow rate was $250 \mathrm{ml} / \mathrm{min}$, which was equivalent to a linear velocity in the reactor of $1.22 \mathrm{~cm} / \mathrm{sec}$. The experiments were performed at four temperatures in the range 175 $250^{\circ} \mathrm{C}$ with reaction times of $30 \mathrm{~min}$.

The results obtained from these experiments, together with the experimental conditions, used are listed in Table III. The values of the

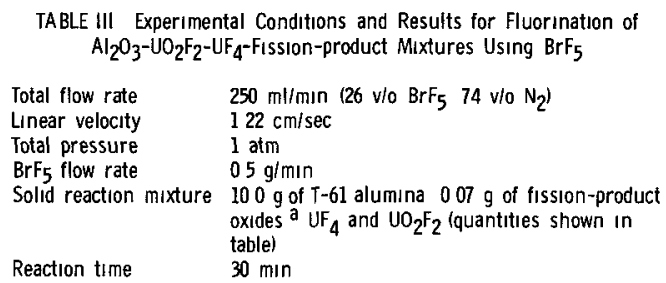

\begin{tabular}{ccccccccc}
\hline $\begin{array}{l}\text { Reaction } \\
\text { Temp }{ }^{\circ} \mathrm{C}\end{array}$ & \multicolumn{2}{c}{$\mathrm{U}$ in Origınal Mixture $\mathrm{g}$} & & & $\begin{array}{c}\text { Fraction of U } \\
\text { Reacted }\end{array}$ & $\begin{array}{c}\text { Rate Constant } \\
\mathrm{k}^{\prime}\end{array} \mathrm{mIn}^{-1}$ \\
\hline \multirow{2}{*}{175} & 1650 & 3217 & 4867 & 3395 & 1472 & 0302 & 00038 \\
200 & 1832 & 3223 & 5055 & 2276 & 2779 & 0550 & 00078 \\
225 & 1833 & 3217 & 5050 & 1360 & 3690 & 0731 & 00118 \\
& 1652 & 3215 & 4867 & 1169 & 3698 & 0760 & 00126 \\
250 & 1831 & 3216 & 5047 & 0628 & 4419 & 0876 & 00167 \\
& 1649 & 3219 & 4868 & 0575 & 4293 & 0882 & 00170
\end{tabular}

aFor composition of fission-product mixture see Table II 
fraction of uranium reacted varied from 0.3 at $175^{\circ} \mathrm{C}$ to 0.9 at $250^{\circ} \mathrm{C}$. Values of the reaction rate constant, $\mathrm{k}^{\prime}$, calculated from these data varied from $0.0038 \mathrm{~min}^{-1}$ at $175^{\circ} \mathrm{C}$ to $0.017 \mathrm{~min}^{-1}$ at $250^{\circ} \mathrm{C}$. The logarithms of the rate constants are plotted in Fig. 4 against $1 / \mathrm{T}$, together with calculated data for a mixture composed of $\mathrm{UO}_{2} \mathrm{~F}_{2}$ and $\mathrm{UF}_{4}$ in the ratio of 2:1. The theoretical plot was obtained from preliminary kinetic data for the reaction of $\mathrm{BrF}_{5}$ with $\mathrm{UF}_{4}$ and $\mathrm{UO}_{2} \mathrm{~F}_{2}$. The preliminary data are represented by the following equations:

$$
\begin{aligned}
& \mathrm{UF}_{4}: \log \mathrm{k}^{\prime}=5.719-3948 / \mathrm{T}, \quad \mathrm{E}=18 \mathrm{kcal} / \mathrm{mole} ; \\
& \mathrm{UO}_{2} \mathrm{~F}_{2}: \log \mathrm{k}^{\prime}=1.493-1747 / \mathrm{T}, \quad \mathrm{E}=8.0 \mathrm{kcal} / \mathrm{mole} .
\end{aligned}
$$

The line through the experimental points was derived from the experimental data by a least-squares solution, which resulted in the following equation:

$$
\log \mathrm{k}^{\prime}=2.020-\frac{1970}{\mathrm{~T}}
$$

Comparison of the experimental and calculated rate constants shows reasonably good agreement; the experimental values are about $20 \%$ higher than the calculated values. The apparent activation energy calculated by means of Eq. 3 is $9.0 \mathrm{kcal} / \mathrm{mole}$; the apparent activation energy calculated for a mixture of $(2 / 3) \mathrm{UO}_{2} \mathrm{~F}_{2}-(1 / 3) \mathrm{UF}_{4}$ is $11.2 \mathrm{kcal} / \mathrm{mole}$.

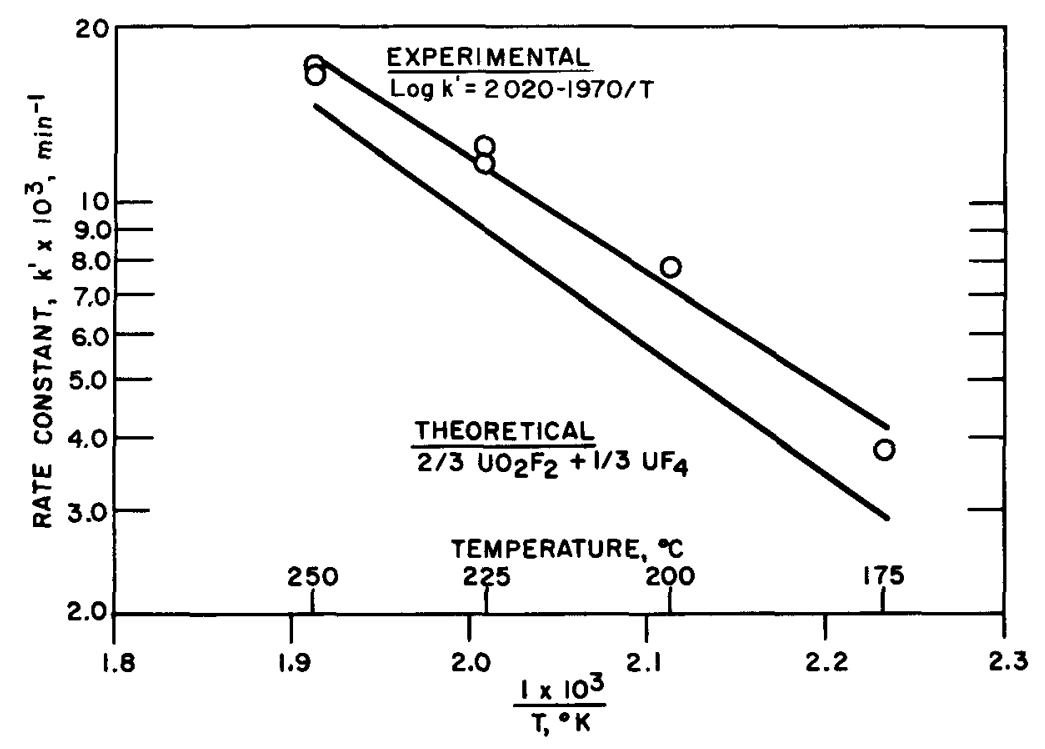

$108-9107$ Rev. 1

Fig. 4. Variation of Rate Constants for Reaction of Mixtures of $\mathrm{UF}_{4}$ and $\mathrm{UO}_{2} \mathrm{~F}_{2}$ with $\mathrm{BrF}_{5}$ over Range $175-250^{\circ} \mathrm{C}$

A series of experiments was performed with a solid reaction mixture similar to that described above to evaluate the effect of adding decladding product materials on the extent of uranium removal by fluorination. The reaction mixture, with and without added decladding product 
materials, was reacted with $\mathrm{BrF}_{5}$ at 250 or $300^{\circ} \mathrm{C}$ for reaction times of $60 \mathrm{~min}$. In the first two experiments, the solid reaction mixture contained

TABLE IV Effect of Temperature and Presence of Stainless Steel or Zircaloy Decladdıng Product on Reaction between $\mathrm{BrF}_{5}$ and Uranıum, Alumına, and Fission-product Mixtures

$\begin{array}{ll}\text { Reaction time. } & 60 \mathrm{mIn} \\ \text { BrF5 flow rate. } & 0.5 \mathrm{~g} / \mathrm{min} \\ \text { Total gas flow rate. } 250 \mathrm{ml} / \mathrm{m} \text { in at } 25^{\circ} \mathrm{C} \\ & (74 \mathrm{v} / \mathrm{o} \mathrm{N} 2,26 \mathrm{v} / 0 \mathrm{BrF} 5) \\ \begin{array}{cl}\text { Linear velocity of } \\ \text { gas at } 25^{\circ} \mathrm{C} .\end{array} & 1.22 \mathrm{~cm} / \mathrm{sec}\end{array}$

\begin{tabular}{|c|c|c|c|c|c|}
\hline $\begin{array}{l}\text { Temp, } \\
{ }^{\circ} \mathrm{C}\end{array}$ & Additive & $\begin{array}{c}\text { Uranıum } \\
\text { Volatılızed, } \\
\%\end{array}$ & $\begin{array}{l}\text { Temp, } \\
{ }^{\circ} \mathrm{C}\end{array}$ & Additive & $\begin{array}{c}\text { Uranium } \\
\text { Volatılized, } \\
\%\end{array}$ \\
\hline \multicolumn{3}{|c|}{ A. $\mathrm{UO}_{2} \mathrm{~F}_{2}-\mathrm{UF}_{4}$-Alumına-F P. Muxtures ${ }^{\mathrm{b}}$} & B & $\mathrm{U}_{3} \mathrm{O}_{8}$-Alumına-F $\mathrm{P}$ & Mixtures ${ }^{e}$ \\
\hline 250 & None & 98.2 & 350 & None & 97.6 \\
\hline 300 & None & 99.8 & 400 & None & 99.8 \\
\hline 300 & $55^{\mathrm{C}}$ & 996 & 400 & $\mathrm{SS}^{\mathrm{C}}$ & 998 \\
\hline 300 & ZIrcd & 992 & 400 & Zurc ${ }^{d}$ & 99.6 \\
\hline
\end{tabular}

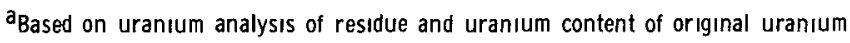
compounds

bMixtures contained $4.2 \mathrm{~g}$ of $\mathrm{UO}_{2} \mathrm{~F}_{2}, 2.2 \mathrm{~g}$ of $\mathrm{UF}_{4}, 10 \mathrm{~g}$ of alumina, and $007 \mathrm{~g}$ of fission product (see Table II for composition of fission-product mixture)

CThe stainless steel decladding product was prepared by the HF-promoted oxıdation of Type 304 stainless steel and contained $47.6 \% \mathrm{Fe}$ and $12.8 \% \mathrm{Cr} ; 0.89 \mathrm{~g}$ of the decladding product was added to the solıd mixtures described in $b$ and $e$.

dThe Zircaloy decladding product was prepared by the HF-promoted oxidation reaction and was primarily $\mathrm{ZrF}_{4} ; 2.6 \mathrm{~g}$ of the decladding product was added to the solid mixtures described in $b$ and $e$

eMixtures contained $5.9 \mathrm{~g}$ of $\mathrm{U} 308,10 \mathrm{~g}$ of alumina, $0.07 \mathrm{~g}$ of fission product (see footnote b). only $\mathrm{Al}_{2} \mathrm{O}_{3}, \mathrm{UO}_{2} \mathrm{~F}_{2}, \mathrm{UF}_{4}$, and fission-product oxides. In the third experiment, $0.89 \mathrm{~g}$ of stainless steel decladding product, prepared by the HFpromoted oxidation of Type 304 stainless steel, was added to the mixture. In the fourth experiment, $2.6 \mathrm{~g}$ of Zircaloy decladding product, formed by the HF-promoted oxidation of Zircaloy, was added to the mixture. After reaction with $\mathrm{BrF}_{5}$, the uranium content of these samples was determined by means of X-ray fluorescence analysis. The data obtained are listed in Part A of Table IV. The fractional removal of uranium from the mixtures containing no decladding products was 98.2 and $99.8 \%$

for the experiments at 250 and $300^{\circ} \mathrm{C}$, respectively. For the experiments in which decladding products were present, the fractional removal of uranium was 99.2 and $99.6 \%$ for Zircaloy decladding product and stainless steel decladding product, respectively. The concentrations of the principal elemental constituents of the decladding products ( $t$ in and zirconium for Zircaloy and iron and chromium for stainless steel) were monitored by means of $\mathrm{X}-\mathrm{ray}$ fluorescence analysis and indicated that no volatilization of the component elements occurred during the $\mathrm{BrF}_{5}$ fluorination.

These results indicate that a reaction temperature of $300^{\circ} \mathrm{C}$ and a reaction time of $60 \mathrm{~min}$ are needed to remove more than $99 \%$ of the uranium from such solid reaction mixtures. Further, the results show that the presence of Zircaloy or stainless steel decladding product in the solid mixtures will not hinder uranium removal, and that the components of the decladding products were not volatilized during fluorination.

\section{Fluorınation of $\mathrm{U}_{3} \mathrm{O}_{8}$-Alumina-Fission-product Mixture}

Experiments were performed to determine the extent of uranlum conversion to $\mathrm{UF}_{6}$ by the reaction of $\mathrm{BrF}_{5}$ with mixtures containing $\mathrm{U}_{3} \mathrm{O}_{8}$, alumina, and fission products, and with such mixtures to which was added either stainless steel or Zircaloy decladding product prepared by the $\mathrm{HF}$-promoted oxidation reaction. Preliminary fluorinations, using only $\mathrm{U}_{3} \mathrm{O}_{8}$, 
had indicated that a temperature of $350^{\circ} \mathrm{C}$ or greater and a reaction time of about 60 min would be needed to convert $99 \%$ or more of the uranium to $\mathrm{UF}_{6}$. The solid reaction mixtures contained $5.9 \mathrm{~g}$ of $\mathrm{U}_{3} \mathrm{O}_{8}, 10 \mathrm{~g}$ of alumina, $0.07 \mathrm{~g}$ of fission-product mixture, and, in some experiments, either $0.89 \mathrm{~g}$ of stainless steel decladding product or $2.6 \mathrm{~g}$ of Zircaloy decladding product. The experiments were performed at reaction temperatures of 350 or $400^{\circ} \mathrm{C}$; the reaction time was $60 \mathrm{~min}$. The $\mathrm{BrF}_{5}$ flow rate was about $0.5 \mathrm{~g} / \mathrm{min}$ in a gas phase containing $26 \mathrm{v} / \mathrm{O} \mathrm{BrF}_{5}$ and $74 \mathrm{v} / \mathrm{o}$ nitrogen at a total flow rate (at $25^{\circ} \mathrm{C}$ ) of $250 \mathrm{ml} / \mathrm{min}$.

The results obtained for these experiments are listed in Part B of Table IV. The results show that $400^{\circ} \mathrm{C}$ is necessary for conversion of $99 \%$ or more of the uranium to $\mathrm{UF}_{6}$. The data also show that the presence of stainless steel or Zircaloy decladding product in the solid reaction mixture did not affect the conversion of uranium to $U F_{6}$. The principal difference between the mixtures containing $\mathrm{U}_{3} \mathrm{O}_{8}$ and those containing $\mathrm{UO}_{2} \mathrm{~F}_{2}$ and $\mathrm{UF}_{4}$ was that a higher temperature was required for high conversion to $\mathrm{UF}_{6}$ for the mixtures containing $\mathrm{U}_{3} \mathrm{O}_{8}$. The concentrations of the principal elemental constituents of the decladding products were monitored by X-ray fluorescence analysis of the reaction residues to determine whether any of the se elements were volatilized during the $\mathrm{BrF}_{5}$ fluorination. The analyses indicated that no volatilization of the component elements had occurred during the $\mathrm{BrF}_{5}$ fluorination.

\section{Fluorination of $\mathrm{U}_{3} \mathrm{O}_{8}-\mathrm{PuO}_{2}$-Alumina-Fission-product Mixtures}

In a series of experiments, solid reaction mixtures containing $\mathrm{U}_{3} \mathrm{O}_{8}, \mathrm{PuO}_{2}$, alumina, and fission products or mixtures containing only $\mathrm{PuO}_{2}$ and alumina were reacted with $\mathrm{BrF}_{5}$ to determine if any of the plutonium would be converted to $\mathrm{PuF}_{6}$. The reaction conditions chosen $\left(400^{\circ} \mathrm{C}, 60-\mathrm{min}\right.$ reaction time, gas phase containing $26 \mathrm{v} / \mathrm{o} \mathrm{BrF}$ and $74 \mathrm{v} / 0$ nitrogen at a total flow rate of $250 \mathrm{ml} / \mathrm{min}$ ) were those that resulted in the conversion of more than $99 \%$ of the uranium to $\mathrm{UF}_{6}$ in previously reported experiments. In two experiments in which the solid reactant contained $\mathrm{U}_{3} \mathrm{O}_{8}(5.8 \mathrm{~g}), \mathrm{PuO}_{2}$ $(0.2 \mathrm{~g}), *$ fission products $(0.07 \mathrm{~g})$, and alumina $(10 \mathrm{~g})$, the reaction residue remaining after the $\mathrm{BrF}_{5}$ reaction was fluorinated with elemental fluorine at $550^{\circ} \mathrm{C}$ using gas-phase recycle conditions.

To determine if plutonium was volatilized during the $\mathrm{BrF}_{5}$ step, all the gaseous reaction products $\left(\mathrm{UF}_{6}\right.$, excess $\mathrm{BrF}_{5}$, bromine, and $\mathrm{PuF}_{6}$ if any was produced) leaving the reactor were passed through a trap, containing soda lime at $100^{\circ} \mathrm{C}$, to convert the reaction products to nonvolatile material. After termination of the $\mathrm{BrF}_{5}$ step, the contents of the trap were removed, ground to a fine powder, and homogenized, and samples were taken

* The ratio of plutonium to uranium $(1: 25)$ in these mixtures was greater by a factor of 10 than the $1: 250$ ratio in the nominal fuel $(0.4 \mathrm{w} / \mathrm{o}$ plutonium in uranium). 
and analyzed for uranium and plutonium content. To determine the background concentration of plutonium in the sample-preparation equipment, portions of unreacted, plutonium-free soda lime were also ground and sampled prior to grinding of the soda lime from the trap.

For two experiments in which the starting material contained both uranium and plutonium, the soda lime after the $\mathrm{BrF}_{5}$ step contained $0.94 \times 10^{-3}$ and $0.44 \times 10^{-3} \mathrm{mg}$ of plutonium per gram of solid. These concentrations represent 0.24 and $0.11 \mathrm{mg}$ of plutonium on the soda lime, corresponding to 0.13 and $0.06 \%$ of the original plutonium in the starting material, respectively. However, blanks of soda lime ground just prior to grinding of the experimental samples had $2.8 \times 10^{-3}$ and $0.56 \times 10^{-3} \mathrm{mg}$ of plutonium per gram of solid for the first and second experiments, respectively. The apparatus used to grind the soda lime samples had been previously used to grind solid samples from a fluid-bed reactor using plutonium. The level of plutonium found in the blank samples strongly suggests that the plutonium contents of the experimental samples were the result of crosscontamination during the grinding operation. In an experiment in which the solid reaction mixture contained only $\mathrm{PuO}_{2}$ and alumina, the initial quantity of $\mathrm{PuO}_{2}$ was greater by a factor of ten than in the other two experiments. After the $\mathrm{BrF}_{5}$ step, the soda lime contained $0.33 \times 10^{-3} \mathrm{mg}$ of plutonium per gram of solid, which again could be attributed to cross-contamination during the grinding operation. In this experiment, the weight gain of the solid reaction mixture indicated that $88 \%$ of the $\mathrm{PuO}_{2}$ had been converted to $\mathrm{PuF}_{4}$. In two separate experiments, which were terminated after the $\mathrm{BrF}_{5}$ step, the uranium content of the solid reaction mixture after the $\mathrm{BrF}_{5}$ fluorination period was determined. These solid residues showed an average concentration of $0.067 \mathrm{w} / \mathrm{o}$ uranium, equivalent to $>99.9 \%$ removal of uranium.

The solid reaction residues remaining after the $B r F_{5}$ step for the first two experiments were fluorinated using $100 \%$ fluorine at $550^{\circ} \mathrm{C}$ for 5 or $8 \mathrm{hr}$ under recycle conditions. The alumina residues after reaction with fluorine contained 0.011 and $0.038 \mathrm{w} / \mathrm{o}$ plutonium and 0.010 and $0.018 \mathrm{w} / 0$ uranium for the 8- and 5-hr fluorinations, respectively. The plutonium concentrations on the alumina correspond to removal of 99.5 and $97.7 \%$ of the plutonium originally contained in the solid mixtures for the 8- and 5-hr tests, respectively. The uranium concentrations on the alumina correspond to removal of more than $99 \%$ of the original uranium present.

These results indicate that essentially none of the plutonium is converted to a volatile form by reaction with $\mathrm{BrF}_{5}$ at $400^{\circ} \mathrm{C}$ for $1 \mathrm{hr}$, and that $99 \%$ or more of the plutonium remaining in the solid mixture can be converted to $\mathrm{PuF}_{6}$ by a subsequent fluorination using fluorine at $550^{\circ} \mathrm{C}$ and a reaction period of less than $10 \mathrm{hr}$. 


\section{Comparison of Reactivity of $\mathrm{BrF}_{5}$ and Fluorine}

A series of experiments was performed in which $\mathrm{UF}_{4}$ or $\mathrm{UO}_{2} \mathrm{~F}_{2}$ or mixtures containing $\mathrm{UF}_{4}, \mathrm{UO}_{2} \mathrm{~F}_{2}$, alumina, and fission-product oxides were reacted with fluorine to obtain reaction data suitable for comparison with similar rate data obtained with $\mathrm{BrF}_{5}$. The data obtained are listed in Table $\mathrm{V}$. The reactions with fluorine were carried out using the reaction conditions listed in Table III.

TABLE V. Reaction Rate Constants, $k^{\prime}$, for Reactions Using $\mathrm{BrF}_{5}$ or Fluorine as Fluorinating Agent

\begin{tabular}{|c|c|c|c|c|c|c|}
\hline \multirow{3}{*}{$\begin{array}{l}\text { Temp, } \\
{ }^{\circ} \mathrm{C}\end{array}$} & \multicolumn{6}{|c|}{ Reaction Rate Constant, $\mathrm{k}^{\prime}, \min ^{-1}$} \\
\hline & \multicolumn{2}{|c|}{$\mathrm{UO}_{2} \mathrm{~F}_{2}$} & \multicolumn{2}{|c|}{$\mathrm{UF}_{4}$} & \multicolumn{2}{|c|}{$\begin{array}{c}\mathrm{UF}_{4}-\mathrm{UO}_{2} \mathrm{~F}_{2}-\mathrm{Al}_{2} \mathrm{O}_{3} \\
\text { F.P. Oxides }\end{array}$} \\
\hline & $\mathrm{BrF}_{5}$ & $F_{2}$ & $\mathrm{BrF}_{5}$ & $F_{2}$ & $\mathrm{BrF}_{5}$ & $F_{2}$ \\
\hline 200 & 0.0064 & 0.0005 & - & - & - & - \\
\hline 250 & - & - & 0.0145 & 0.0010 & 0.0169 & 0.0013 \\
\hline 275 & - & - & 0.0344 & 0.0040 & - & - \\
\hline 300 & 0.0276 & 0.0008 & - & - & - & - \\
\hline
\end{tabular}

The data show that the rate constants for reactions with fluorine are an order of magnitude lower than those for the reactions using $\mathrm{BrF}_{5}$ as the fluorinating agent. For example, considering a 30-min reaction period: for $\mathrm{UO}_{2} \mathrm{~F}_{2}$ at $300^{\circ} \mathrm{C}$, the fractions reacted would be 0.995 for $\mathrm{BrF}_{5}$ and 0.070 for fluorine; for $U F_{4}$ at $250^{\circ} \mathrm{C}$, the fractions reacted would be 0.820 for $\mathrm{BrF}_{5}$ and 0.087 for fluorine; and for the $\mathrm{UF}_{4}-\mathrm{UO}_{2} \mathrm{~F}_{2}$-alumina-F.P. mixtures at $250^{\circ} \mathrm{C}$, the fractions reacted would be 0.873 for $\mathrm{BrF}_{5}$ and 0.112 for fluorine. The increased reaction rates when $\mathrm{BrF}_{5}$ is employed as the fluorinating agent for uranium should shorten the time required to process a batch of oxide fuel.

\section{B. Kinetic Studies}

The kinetics of the reaction of gaseous $\mathrm{BrF}_{5}$ with the compounds, $\mathrm{UF}_{4}, \mathrm{UO}_{2} \mathrm{~F}_{2}, \mathrm{U}_{3} \mathrm{O}_{8}, \mathrm{UO}_{2}$, and $\mathrm{UO}_{3}$ has been studied. No previous study of these reactions has been reported. Both the temperature and pressure dependence of the reaction rates have been determined. These basic data on materials of interest to the FBFVP will allow estimation of the rates of reaction in process equipment.

Previously reported studies of the reactions of uranium compounds with interhalogen compound have included reactions of $\mathrm{ClF}_{3}$ with $\mathrm{UF}_{4},{ }^{9-12}$ $\mathrm{UO}_{2} \mathrm{~F}_{2},{ }^{13,14}$ and various uranium oxides, ${ }^{15}$ and the reaction between $\mathrm{BrF}_{3}$ and $\mathrm{U}_{3} \mathrm{O}_{8} \cdot{ }^{16}$ 
It has been found convenient to treat the data obtained from such gassolid heterogeneous reactions by means of the "diminishing-sphere" model developed by Anderson. ${ }^{17}$ Two examples of the use of this reaction model are the work of Labaton ${ }^{9}$ on the $\mathrm{UF}_{4}-\mathrm{ClF}_{3}$ reactions and that of Johnson and Fischer ${ }^{6}$ on the reaction of $\mathrm{SF}_{4}$ with $\mathrm{UO}_{3}$ and $\mathrm{UO}_{2} F_{2}$. The following development of the kinetic equation for the diminishing sphere model is from the paper of Johnson and Fischer. ${ }^{6}$

Assuming a solid reactant consisting of uniform spherical particles upon which the gaseous reactant acts, and assuming that the reaction starts at $t=0$ on all particles, we can deduce the following reactionship:

If the initial mass of a solid particle $M_{0}=(4 / 3) \pi r_{0}^{3} \rho$, where $r_{0}=$ initial radius and $\rho=$ bulk density, then the rate of reduction in mass at a given temperature is assumed to be proportional to the surface area of the particle. That is,

$$
-\frac{\mathrm{dM}}{\mathrm{dt}}=4 \pi \mathrm{r}^{2} \mathrm{k}
$$

where $r$ is the radius of the particle at time $t$, and $k$ is the constant for $a$ given temperature and a given partial pressure of reactant gas.

The fraction of reaction $F$ that has taken place in time $t$ is given by

$$
F=\frac{M_{0}-M}{M_{0}}=1-\left(\frac{r}{r_{0}}\right)^{3} \text {, }
$$

which when substituted in Eq. 4 becomes

$$
\left.\begin{array}{l}
\frac{d M}{d t}=-4 \pi r_{0}^{2} k(1-F)^{2 / 3} ; \\
\frac{d F}{d t}=\frac{1}{M_{0}} \frac{d M}{d t}=\frac{3 k}{r_{0} \rho}(1-F)^{2 / 3} .
\end{array}\right\}
$$

Integrating Eq. 5, we obtain

$$
(1-F)^{1 / 3}=1-k^{\prime} t
$$

where $\mathrm{k}^{\prime}=\mathrm{k} / \mathrm{r}_{0} \rho$.

When $(1-F)^{1 / 3}$ is plotted against the reaction time $t$ for a typical experiment, the points lie on a straight line in agreement with the equation, with the exception of small deviations at the beginning and end of the experiment, which are considered to be due to experimental conditions. The deviation at the beginning, for example, is due to the presence of an inert gas in 
the reactor, and its displacement by the reacting gas requires a small but finite time interval. The deviation at the end of the experiment is usually ascribed to the small amount of solid reactant remaining, or to the presence of a proportionally large fraction of solid intermediate product of lower reactivity.

The kinetics of the reactions with $\mathrm{UF}_{4}, \mathrm{U}_{3} \mathrm{O}_{8}, \mathrm{UO}_{2}$, and $\mathrm{UO}_{3}$ were determined using the thermobalance system; the kinetics for the reaction with $\mathrm{UO}_{2} \mathrm{~F}_{2}$ were determined using the boat-reactor system. It was not possible to use the thermobalance for the $\mathrm{UO}_{2} \mathrm{~F}_{2}$ experiments because of the large temperature rise and concurrent very rapid reaction rate in the initial stages of the reaction. This effect was considered to result from the high surface area of the $\mathrm{UO}_{2} \mathrm{~F}_{2}$. In the boat reactor, the initial temperature rise was damped out by the greater mass of the reactor (see Section II.B above), and the effect of an initially high rate would be minimized by the greater size of the $\mathrm{UO}_{2} \mathrm{~F}_{2}$ sample ( $5 \mathrm{~g}$ for the boat reactor versus $0.3 \mathrm{~g}$ for the thermobalance).

The quantity of solid reactant used, $300 \mathrm{mg}$ for the thermobalance and about $5 \mathrm{~g}$ for the boat reactor, was chosen so that the reaction time at the higher temperatures would not be too short to measure accurately and to provide approximately a one-particle-deep layer of solid on the reaction pan. The thin layer of solid reactant tended to minimize any effect of the formation of intermediates on the rate of reaction. This quantity of solid reactant was also found to be suitable in work by Johnson and Fischer ${ }^{6}$ in a thermobalance study of the kinetics of the reaction of $\mathrm{SF}_{4}$ with $\mathrm{UO}_{3}$ and $\mathrm{UO}_{2} \mathrm{~F}_{2}$.

\section{1. $\mathrm{UF}_{4}-\mathrm{BrF}_{5}$ Reaction}

Kinetic data for the $\mathrm{UF}_{4}-\mathrm{BrF}_{5}$ reaction were determined over the nominal range $200-275^{\circ} \mathrm{C}$ and $\mathrm{a}_{\mathrm{BF}}$ partial-pressure range of $138-$ 370 Torr (corresponding to $\mathrm{BrF}_{5}$ concentrations of 18-49 v/o). The reaction conditions and the values of the rate constant are listed in Table VI.

TABLE VI. Reaction Rate Constants, $\mathrm{k}^{\prime}$, for $\mathrm{UF}_{4}-\mathrm{BrF}_{5}$ Reaction Linear velocity of gas phase, $0.64 \mathrm{~cm} / \mathrm{sec}$;

$\mathrm{UF}_{4}$ sample size, $300 \mathrm{mg}$.

\begin{tabular}{|c|c|c|c|c|c|c|c|c|c|c|c|}
\hline \multirow{2}{*}{$\begin{array}{l}\text { Temp, } \\
{ }^{\circ} \mathrm{C}\end{array}$} & \multicolumn{2}{|c|}{$\begin{array}{l}\text { Rate Constant, } \\
k^{1} \times 10^{3}, \min ^{-1}\end{array}$} & \multirow{2}{*}{$\underset{\min ^{-1}}{\left(k_{\text {calc }}^{\prime}-k_{\text {exp }}^{\prime}\right) \times 10^{3},}$} & \multirow{2}{*}{$\begin{array}{l}\text { Temp, } \\
{ }^{\circ} \mathrm{C}\end{array}$} & \multicolumn{2}{|c|}{$\begin{array}{l}\text { Rate Constant } \\
\mathrm{k}^{\prime} \times 10^{3}, \mathrm{~min}^{-1}\end{array}$} & \multirow{2}{*}{$\begin{array}{c}\left(k_{\text {calc }}^{\prime}-k_{\text {exp }}^{\prime}\right) \times 10^{3}, \\
\min ^{-1}\end{array}$} & \multirow{2}{*}{$\begin{array}{l}\text { Temp, } \\
{ }^{\circ} \mathrm{C}\end{array}$} & \multicolumn{2}{|c|}{$\begin{array}{l}\text { Rate Constant, } \\
k^{\prime} \times 10^{3}, \min ^{-1}\end{array}$} & \multirow{2}{*}{$\begin{array}{c}\left(k_{\text {calc }}^{\prime}-k_{\text {exp }}^{\prime}\right) \times 10^{3} \\
\min ^{-1}\end{array}$} \\
\hline & $\operatorname{Exp}$ & $\mathrm{Calc}^{\mathrm{a}}$ & & & $\operatorname{Exp}$ & $\mathrm{Calc}^{\mathrm{a}}$ & & & $E x p$ & $\mathrm{Calc}^{\mathrm{a}}$ & \\
\hline \multicolumn{4}{|c|}{ A. $\begin{aligned} & \mathrm{P}_{\mathrm{BrF}_{5}}=138 \text { Torr }\left(18 \mathrm{v} / 0 \mathrm{BrF}_{5}, 82 \mathrm{v} / 0 \mathrm{~N}_{2}\right) \\
& \underline{\log \mathrm{k}^{1}}=5.157-3720 / \mathrm{T}\end{aligned}$} & \multicolumn{4}{|c|}{ B. $\frac{\mathrm{P}_{\mathrm{BrF}_{5}}=239 \text { Torr }\left(3 \mathrm{l} \mathrm{v} / 0 \mathrm{BrF}, 69 \mathrm{v} / 0 \mathrm{~N}_{2}\right)}{\log \mathrm{k}^{\prime}=5.181-3690 / \mathrm{T}}$} & \multicolumn{4}{|c|}{ C. $\frac{\mathrm{PBrF}_{5}=370 \text { Torr }\left(49 \mathrm{v} / \mathrm{OBrF}, 51 \mathrm{v} / 0 \mathrm{~N}_{2}\right)}{\log \mathrm{k}^{\prime}=5.185-3650 / \mathrm{T}}$} \\
\hline $\begin{array}{l}200 \\
225 \\
250 \\
274\end{array}$ & $\begin{array}{l}1.97 \\
4.92 \\
11.3 \\
22.7\end{array}$ & $\begin{array}{c}1.98 \\
4.92 \\
11.2 \\
22.9\end{array}$ & $\begin{array}{c}+0.01 \\
0.00 \\
-0.1 \\
+0.2\end{array}$ & $\begin{array}{l}200 \\
210 \\
230 \\
240 \\
262 \\
274\end{array}$ & $\begin{array}{c}2.42 \\
3.62 \\
6.87 \\
10.4 \\
19.0 \\
28.2\end{array}$ & $\begin{array}{c}2.45 \\
3.55 \\
7.14 \\
9.9 \\
19.6 \\
27.7\end{array}$ & $\begin{array}{l}+0.03 \\
-0.07 \\
+0.27 \\
-0.5 \\
+0.6 \\
+0.5\end{array}$ & $\begin{array}{l}199 \\
219 \\
234 \\
249 \\
260\end{array}$ & $\begin{array}{c}2.82 \\
5.90 \\
10.0 \\
15.2 \\
22.2\end{array}$ & $\begin{array}{c}2.84 \\
5.85 \\
9.69 \\
15.6 \\
21.8\end{array}$ & $\begin{array}{l}+0.02 \\
-0.05 \\
-0.31 \\
+0.4 \\
-0.4\end{array}$ \\
\hline
\end{tabular}

aValues in this column were calculated by use of the equations in headings $A, B$, and $C$. 
The effect of temperature on the rate constant is shown in Fig. 5. The integrated form of the Arrhenius equation was fitted to the data by the method of least squares, resulting in the equations listed in Table VI, which represent the temperature dependence of the reaction rates. Values of the apparent activation energy were $17.0,16.9$, and $16.7 \mathrm{kcal} / \mathrm{mole}$ for $\mathrm{BrF}_{5}$ partial pressures of 138,239 , and 370 Torr, respectively.

Values of the rate constant were calculated at selected temperatures; the values are shown in Fig. 6 as plots of $\log \mathrm{k}^{\prime}$ versus the $\log$ of the $\mathrm{BrF}_{5}$ partial pressure. Values of the coefficient $n$, of the pressure term of the equation $k^{\prime}=A e^{-E / R T} P^{n}$ were calculated using the slopes of the plots in Fig. 6. The values of $\mathrm{n}$ obtained ranged from 0.36 to 0.40 . Averaging the constants for the Arrhenius equations and using the average value of the coefficient, $n$, we derived the following equation to represent the simultaneous temperature and pressure dependence of the rate constant for the $\mathrm{UF}_{4}-\mathrm{BrF}_{5}$ reaction:

$$
\log k^{\prime}=4.286-3690 / \mathrm{T}\left({ }^{\circ} \mathrm{K}\right)+0.38 \log \mathrm{P}_{\mathrm{BrF}_{5}}(\operatorname{Torr})
$$

The activation energy calculated using the above equation is $16.9 \mathrm{kcal} / \mathrm{mole}$.

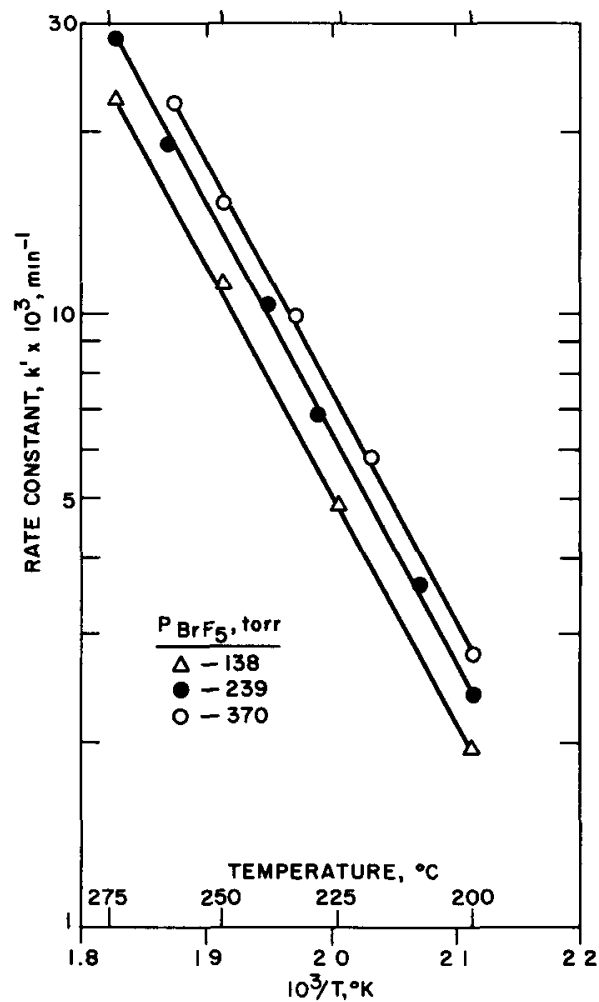

$308-80$

Fig. 5. Temperature Dependence of Rate Constant for $\mathrm{UF}_{4}-\mathrm{BrF}_{5}$ Reaction UF $_{4}$ sample size: $300 \mathrm{mg}$ Linear velocity of gas phase: $\quad 0.64 \mathrm{~cm} / \mathrm{sec}$

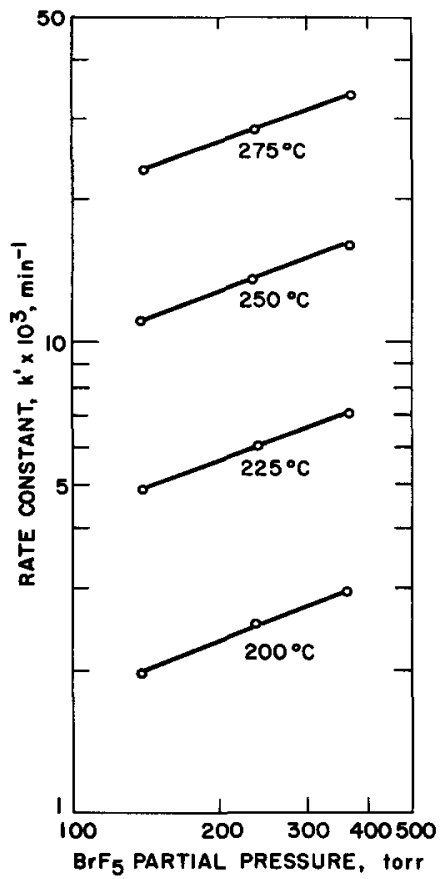

$308-67$

Fig. 6. Effect of BrF 5 Partial Pressure on Rate Constant for $\mathrm{UF}_{4}-\mathrm{BrF}_{5}$ Reaction 
Experiments were performed to determine the effect of the linear velocity of the gas phase on the reaction rate constant. The reactions were performed at $235^{\circ} \mathrm{C}$ using a gas phase containing $32 \mathrm{v} / 0 \mathrm{BrF}{ }_{5}$ (partial pressure of 243 Torr) and $68 \mathrm{v} / \mathrm{o}$ nitrogen. The values of the rate constant obtained at linear velocities of $0.46,0.64$, and $1.28 \mathrm{~cm} / \mathrm{sec}$ were $6.62,6.33$, and $5.80 \times 10^{-3} \mathrm{~min}^{-1}$, respectively. These results show only a $13 \%$ change in the rate constant for a nearly threefold increase in the linear velocity.

The reaction between $\mathrm{UF}_{4}$ and $\mathrm{BrF}_{5}$ is complicated by the formation of intermediate fluorides, $U_{2} F_{9}, U_{4} F_{17}$, and $U F_{5}$, either as a result of the direct reaction or by the interaction of $U F_{6}$ with $U F_{4}$. The possible reactions, using $\mathrm{UF}_{5}$ as the example of the intermediate fluoride, are as follow s:

$$
\begin{aligned}
& 5 \mathrm{UF}_{4}+2 \mathrm{BrF}_{5} \rightarrow 5 \mathrm{UF}_{6}+\mathrm{Br}_{2} \\
& 5 \mathrm{UF}_{4}+\mathrm{BrF}_{5} \rightarrow 5 \mathrm{UF}_{5}+\frac{1}{2} \mathrm{Br}_{2} \\
& \mathrm{UF}_{4}+\mathrm{UF}_{6} \rightarrow 2 \mathrm{UF}_{5} \\
& 5 \mathrm{UF}_{5}+\mathrm{BrF}_{5} \rightarrow 5 \mathrm{UF}_{6}+\frac{1}{2} \mathrm{Br}_{2}
\end{aligned}
$$

Although the color of the reaction residues (either brown or black) indicated the presence of the intermediate compounds, no evidence of an induction period in the history of the weight change of the samples was observed. Evidently the reaction to form volatile $\mathrm{UF}_{6}$ does not require the formation of significant quantities of the intermediate fluorides. Hence, the reaction is believed to proceed by direct conversion of $\mathrm{UF}_{4}$ to $\mathrm{UF}_{6}$. The reaction of $\mathrm{UF}_{4}$ with fluorine has been shown to proceed in a similar manner. Labaton and Johnson ${ }^{18}$ have demonstrated that the $U F_{4}-F_{2}$ reaction did not proceed through a step involving the formation of intermediate fluorides, but rather proceeded by the direct fluorination of $\mathrm{UF}_{4}$ to $\mathrm{UF}_{6}$. These workers also showed that the rate of fluorination of the intermediate fluorides was lower by a factor of 2 to 4 than the rate of fluorination of $U F_{4}$. It is assumed that these relative rates are valid for the fluorination reaction with $\mathrm{BrF}_{5}$ as well.

Equations 6-9 show bromine as a reaction product. Bromine was indicated by the deep red color of the condensed reaction products and was quantitatively assayed by conversion of bromine to $\mathrm{BrF}_{3}$ using the fluorine titration method of Sheft and co-workers. ${ }^{19}$ Fluorine titrations of the condensed products from several experiments showed quantities of $\mathrm{Br}_{2}$ corresponding to the stoichiometry of Reaction 6 above. Bromine could result from the direct reduction of $\mathrm{BrF}_{5}$ to $\mathrm{Br}_{2}$ or from the stepwise reduction to $\mathrm{BrF}_{3}$, which, in turn, would react further to form $\mathrm{Br}_{2}$. In either case, the observed kinetics would be those for the $\mathrm{UF}_{4}-\mathrm{BrF}_{5}$ reaction if the rate of the $\mathrm{UF}_{4}-\mathrm{BrF}_{3}$ reaction is higher than that of the $\mathrm{UF}_{4}-\mathrm{BrF}{ }_{5}$ reaction. Since 
no data are available in the literature for the reaction between $\mathrm{UF}_{4}$ and $\mathrm{BrF}$, boat-reactor experiments were performed to obtain rate data at $200^{\circ} \mathrm{C}$ for the two reactions. For the $\mathrm{UF}_{4}-\mathrm{BrF}_{5}$ reaction at a $\mathrm{BrF}_{5}$ partial pressure of 198 Torr, the rate constant was $0.00235 \mathrm{~min}^{-1}$; for the $\mathrm{UF}_{4}-\mathrm{BrF}_{3}$ reaction at a $\mathrm{BrF}_{3}$ partial pressure of 105 Torr, the rate constant was $0.0145 \mathrm{~min}^{-1}$. These data show clearly that the reaction rate with $\mathrm{BrF}_{3}$ is significantly higher. Therefore, the kinetics measured represent the reaction with $\mathrm{BrF}_{5}$.

The value of the activation energy, $16.9 \mathrm{kcal} / \mathrm{mole}$, found for the $\mathrm{UF}_{4}-\mathrm{BrF} \mathrm{F}_{5}$ reaction is in the range of values reported ${ }^{18,20}$ for the $U F_{4}-F_{2}$ reaction, $14-20 \mathrm{kcal} / \mathrm{mole}$ rather than the $2-6 \mathrm{kcal} / \mathrm{mole}$ reported for the $\mathrm{UF}_{4}-\mathrm{ClF}_{3}$ reaction. ${ }^{9,10}$ The order of the $\mathrm{UF}_{4}-\mathrm{BrF} \mathrm{F}_{5}$ reaction was fractional with respect to $B_{r} F_{5}$ pressure, while the order of both the $U F_{4}-F_{2}$ (Ref. 18) and $\mathrm{UF}_{4}-\mathrm{ClF}_{3}$ (Ref. 9) reactions was unity with respect to the partial pressure of the fluorinating agent. Finally, the temperature dependence of the rate of the $\mathrm{UF}_{4}-\mathrm{BrF}_{5}$ reaction did not show a minimum as was observed for the $\mathrm{UF}_{4}-\mathrm{ClF}_{3}$ reaction; ${ }^{9}$ the latter was ascribed to the formation of intermediate fluorides and a consequent reduction in the rate of volatilization of $\mathrm{UF}_{6}$.

\section{2. $\mathrm{UO}_{2} \mathrm{~F}_{2}-\mathrm{BrF}_{5}$ Reaction}

The overall reaction between $\mathrm{UO}_{2} \mathrm{~F}_{2}$ and $\mathrm{BrF}_{5}$ is considered to proceed as shown in the following equation:

$$
5 \mathrm{UO}_{2} \mathrm{~F}_{2}+4 \mathrm{BrF}_{5} \rightarrow 5 \mathrm{UF}_{6}+2 \mathrm{Br}_{2}+5 \mathrm{O}_{2}
$$

In this reaction, as was shown for the $U F_{4}-B r F_{5}$ reaction, $B r_{2}$ is postulated as a reaction product of the $\mathrm{BrF}_{5}$ component of the reaction. The instability of bromine oxides at temperatures above $0^{\circ} \mathrm{C}$ makes their presence highly improbable. ${ }^{21}$

Boat-reactor experiments were performed to determine the fraction of $\mathrm{UO}_{2} \mathrm{~F}_{2}$ converted to $\mathrm{UF}_{6}$ at several time intervals, temperatures, and $\mathrm{BrF}_{5}$ partial pressures. The data were treated using the diminishingsphere model. Values of $(1-F)^{1 / 3}$ are plotted against reaction time $t$ in Fig. 7 for reactions performed at $250^{\circ} \mathrm{C}$ and $\mathrm{BrF}_{5}$ partial pressures of 130 , 197, and 357 Torr. The lines through the data in Fig. 7 represent the leastsquares equations, from which values of the rate constant, $k^{\prime}$, of 0.0116 , 0.0131 , and $0.0219 \mathrm{~min}^{-1}$ were calculated for partial pressures of $\mathrm{BrF}_{5}$ of 130, 197, and 357 Torr, respectively.

Values of the rate constant, calculated as described above, for data obtained in the nominal temperature range $175-300^{\circ} \mathrm{C}$ and at partial pressures of $\mathrm{BrF}_{5}$ of 130, 197, and 357 Torr are listed in Table VII and shown in Fig. 8. The integrated form of the Arrhenius equation was fitted to the data by the least-squares method; the equations obtained are listed 
in Table VII along with values of $k^{\prime}$ calculated using the se equations. Calculated values of the apparent activation energy are $8.4,8.3$, and $8.0 \mathrm{kcal} /$ mole, for $\mathrm{BrF}_{5}$ partial pressures of 130,197 , and 357 Torr, respectively.

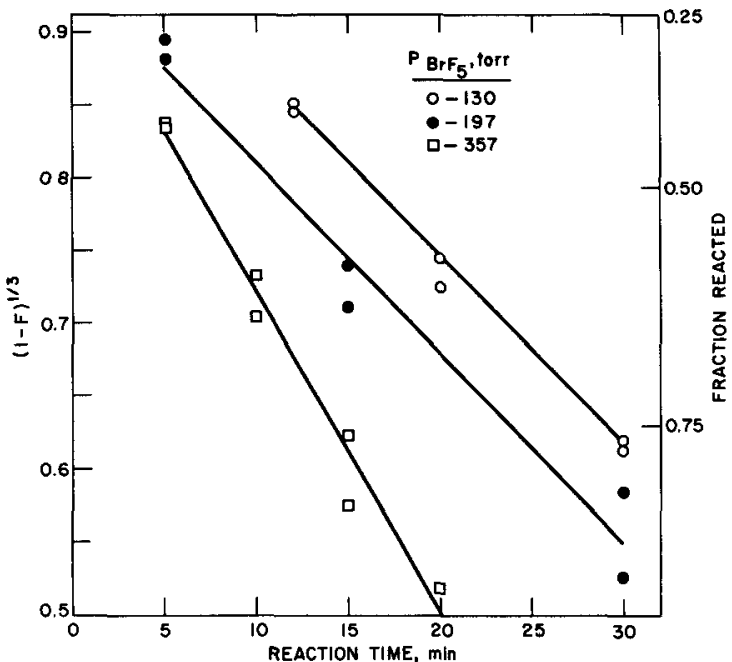

$308-84$
Fig. 7

Effect of $\mathrm{BrF}_{5}$ Partial Pressure on Conversion of Uranium to $\mathrm{UF}_{6}$ for $\mathrm{UO}_{2} \mathrm{~F}_{2}-\mathrm{BrF}_{5}$ Reaction at $250^{\circ} \mathrm{C}$

Sample size: $\quad 5 \mathrm{~g}$

Linear velocity of gas phase: $0.85 \mathrm{~cm} / \mathrm{sec}$

TABLE VII. Reaction Rate Constants, $k^{\prime}$, for $\mathrm{UO}_{2} \mathrm{~F}_{2}-\mathrm{BrF}_{5}$ Reaction

Linear velocity of gas phase, $0.86 \mathrm{~cm} / \mathrm{sec}$;

$\mathrm{UO}_{2} \mathrm{~F}_{2}$ sample size, $5 \mathrm{~g}$.

\begin{tabular}{|c|c|c|c|c|c|c|c|c|c|c|c|}
\hline \multirow{2}{*}{$\underset{{ }^{\circ} \mathrm{C}}{\text { Temp }}$} & \multicolumn{2}{|c|}{$\begin{array}{l}\text { Rate Constant, } \\
\mathbf{k}^{\prime} \times 10^{3}, \text { min }^{-1} \\
\end{array}$} & \multirow{2}{*}{$\begin{array}{c}\left(k_{\text {calc }}^{\prime}-k_{\text {exp }}^{\prime}\right) \times 10^{3} \\
\min ^{-1}\end{array}$} & \multirow{2}{*}{$\begin{array}{l}\text { Temp, } \\
{ }^{\circ} \mathrm{C}\end{array}$} & \multicolumn{2}{|c|}{$\begin{array}{l}\text { Rate Constant, } \\
k^{\prime} \times 10^{3}, \text { min }^{-1} \\
\end{array}$} & \multirow{2}{*}{$\underset{\min ^{-1}}{\left(k_{\text {calc }}^{\prime}-k_{\text {exp }}^{\prime}\right) \times 10^{3}}$} & \multirow{2}{*}{${ }^{\circ} \mathrm{C}$} & \multicolumn{2}{|c|}{$\begin{array}{l}\text { Rate Constant, } \\
k^{\prime} \times 10^{3}, \text { min }^{-1}\end{array}$} & \multirow{2}{*}{$\begin{array}{c}\left(k_{\text {calc }}^{\prime}-k_{\text {exp }}^{\prime}\right) \times 10^{3} \\
\min ^{-1}\end{array}$} \\
\hline & $\operatorname{Exp}$ & Calc $^{\mathbf{a}}$ & & & Exp & Calc $^{\mathrm{a}}$ & & & Exp & Calca $^{a}$ & \\
\hline & $5=13$ & Torr 117 & $10 \mathrm{BrF}_{5}, 83 \mathrm{v} / 0 \mathrm{~N} \mathrm{~N}_{2}$ & \multicolumn{4}{|c|}{ B. $\mathrm{P}_{\mathrm{BrF}_{5}}=197$ Torr $\left(30 \mathrm{v} / 0 \mathrm{BrF}_{5}, 70 \mathrm{v} / 0 \mathrm{~N}_{2}\right)$} & \multicolumn{4}{|c|}{ C. $\mathrm{P}_{\mathrm{BrF}_{5}}=357$ Torr $(47 \mathrm{v} / 0 \mathrm{BrF}, 53 \mathrm{v} / 0 \mathrm{~N})^{\prime}$} \\
\hline & \multicolumn{3}{|c|}{$\log \mathrm{k}^{\prime}=1.561-1850 / \mathrm{T}$} & \multicolumn{3}{|c|}{$\log k^{\prime}=1.484-1740 / T$} & & \multicolumn{3}{|c|}{$\log k^{\prime}=1.848-1830 / T$} & \\
\hline $\begin{array}{l}200 \\
225 \\
250 \\
275 \\
300\end{array}$ & $\begin{array}{c}4.30 \\
7.42 \\
11.6 \\
15.9 \\
20.5\end{array}$ & $\begin{array}{c}4.57 \\
7.17 \\
10.8 \\
15.6 \\
21.9\end{array}$ & $\begin{array}{l}+0.27 \\
-0.25 \\
-0.8 \\
-0.3 \\
+1.4\end{array}$ & $\begin{array}{l}175 \\
200 \\
225 \\
250 \\
275 \\
300\end{array}$ & $\begin{array}{c}4.04 \\
5.97 \\
10.5 \\
13.1 \\
21.2 \\
27.6\end{array}$ & $\begin{array}{c}3.99 \\
6.41 \\
9.8 \\
14.4 \\
20.4 \\
28.1\end{array}$ & $\begin{array}{l}-0.05 \\
+0.44 \\
-0.7 \\
+1.3 \\
-0.8 \\
+0.5\end{array}$ & $\begin{array}{l}212 \\
225 \\
250 \\
275 \\
300\end{array}$ & $\begin{array}{l}10.4 \\
16.9 \\
21.9 \\
32.0 \\
43.2\end{array}$ & $\begin{array}{l}11.7 \\
14.7 \\
22.0 \\
31.8 \\
44.5\end{array}$ & $\begin{array}{l}+1.3 \\
-2.2 \\
+0.1 \\
-0.2 \\
+1.3\end{array}$ \\
\hline
\end{tabular}

${ }^{a}$ Values in this column were calculated by use of the equations in headings $A, B$, and $C$.

Fig. 8

Temperature Dependence of Rate Constant for $\mathrm{UO}_{2} \mathrm{~F}_{2}-\mathrm{BrF}_{5}$ Reaction

Sample size:

$5 \mathrm{~g}$

Linear velocity of gas phase: $0.86 \mathrm{~cm} / \mathrm{sec}$

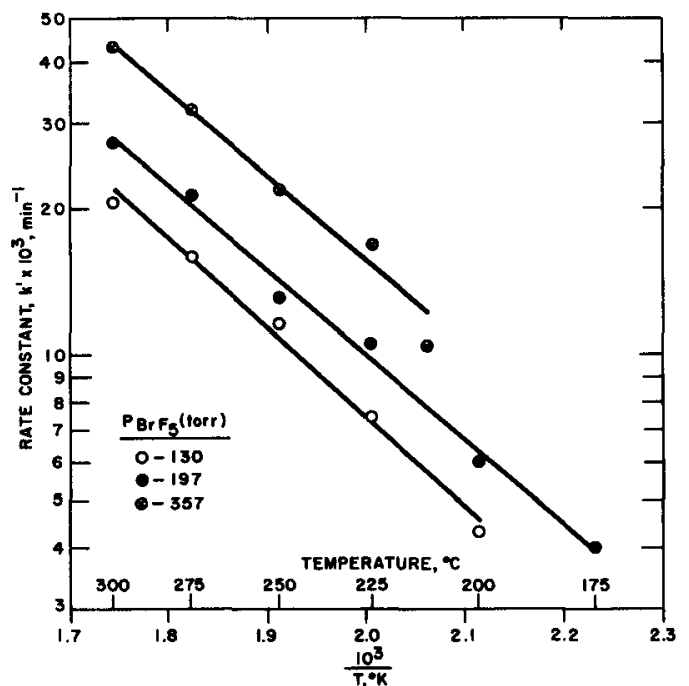

$308-96$ 


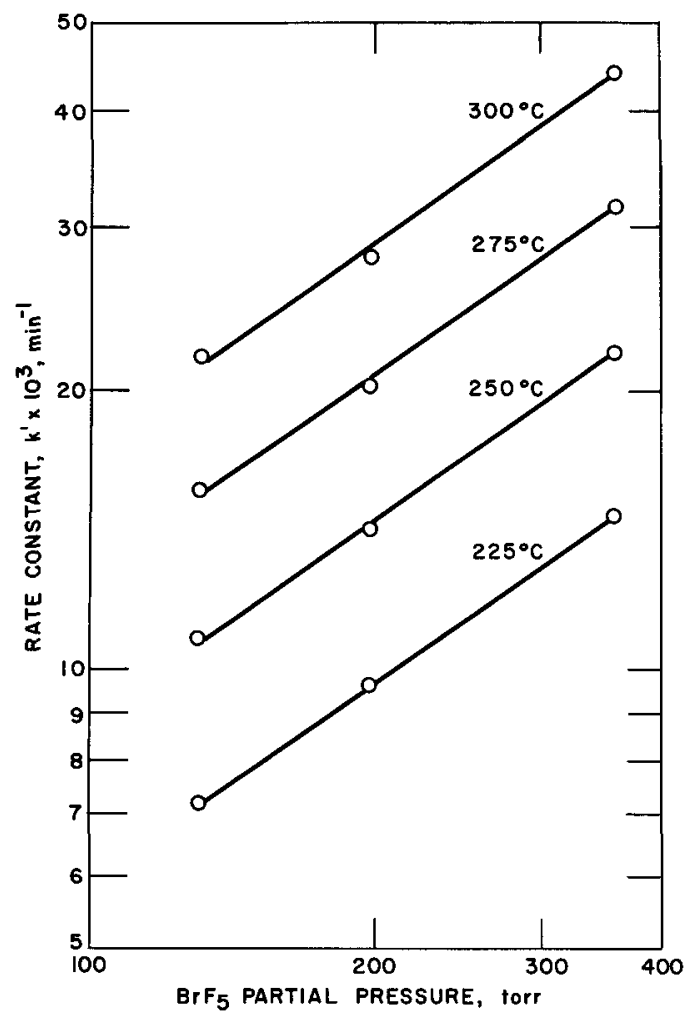

$308-82$

Fig. 9. Effect of $\mathrm{BrF}_{5}$ Partial Pressure on Rate Constant for $\mathrm{UO}_{2} \mathrm{~F}_{2}-\mathrm{BrF}_{5}$ Reaction
Values of the rate constant were calculated at selected temperatures, and Fig. 9 shows the values as plots of $\log k^{\prime}$ versus the log of the partial pressure of $\mathrm{BrF}_{5}$. Values of the coefficient, $n$, of the pressure term of the equation $k^{\prime}=$ Ae-E/RTPn were calculated using the slope of the plots of Fig. 9. The values obtained range from 0.70 to 0.71 . The following equation was derived to represent the simultaneous temperature and pressure dependence of the rate constant for the $\mathrm{UO}_{2} \mathrm{~F}_{2}-\mathrm{BrF}{ }_{5}$ reaction:

$\log k^{\prime}=-\frac{1810}{\mathrm{~T}\left({ }^{\circ} \mathrm{K}\right)}+0.71 \log \mathrm{P}_{\mathrm{BrF}_{5}}$ (Torr).

The activation energy calculated using the above equation is $8.3 \mathrm{kcal} / \mathrm{mole}$.

The effect of the linear velocity of the gas phase upon the rate constant was investigated in a series of experiments performed at $250^{\circ} \mathrm{C}$ with a $\mathrm{BrF}_{5}$ partial pressure of 197 Torr. Values of the rate constant were $0.0135,0.0131$,

and $0.0122 \mathrm{~min}^{-1}$ at gas-phase linear velocities of $0.86,1.28$, and $2.92 \mathrm{~cm} /$ sec, respectively. These results show less than a $10 \%$ change in the rate constant for a greater than threefold increase in the linear velocity, indicating a small effect of the linear velocity on the rate constant.

Previous studies of fluorinations of $\mathrm{UO}_{2} \mathrm{~F}_{2}$ include the reaction with $\mathrm{ClF}_{3}$ (Refs. 13 and 22), with fluorine, ${ }^{21,24}$ and with $\mathrm{SF}_{4}$ (Ref. 6). Activation energies for these reactions are $\mathrm{ClF}_{3}, 10.2 \mathrm{kcal} / \mathrm{mole}$; $^{22}$ fluorine, $19.5 \mathrm{kcal} / \mathrm{mole}^{24}$ and $\mathrm{SF}_{4}, 32 \mathrm{kcal} / \mathrm{mole}{ }^{6}$ The dependence of the rate constant on the partial pressure of the fluorinating gas was first order for the $\mathrm{UO}_{2} \mathrm{~F}_{2}-\mathrm{ClF}_{3}$ reaction 22 and proportional to the 1.5 power for the $\mathrm{UO}_{2} \mathrm{~F}_{2}-\mathrm{SF}_{4}$ reaction. ${ }^{6}$ The present investigation of the $\mathrm{UO}_{2} \mathrm{~F}_{2}-\mathrm{BrF} \mathrm{F}_{5}$ reaction showed an activation energy of $8.3 \mathrm{kcal} /$ mole and an order of pressure dependence of 0.71 , which is similar to the results for the $\mathrm{UO}_{2} \mathrm{~F}_{2}-\mathrm{ClF}_{3}$ reaction rather than those for the $\mathrm{UO}_{2} \mathrm{~F}_{2}-\mathrm{SF}_{4}$ reactions.

\section{3. $\mathrm{U}_{3} \mathrm{O}_{8}-\mathrm{BrF}_{5}$ Reaction}

The kinetics of the $\mathrm{U}_{3} \mathrm{O}_{8}-\mathrm{BrF}_{5}$ reaction were determined at $\mathrm{BrF}_{5}$ partial pressures of $89,108,189,241$, and $369 \mathrm{Tor}$, and in the nominal temperature range $225-360^{\circ} \mathrm{C}$. The values of the rate constant are 
listed in Table VIII and plotted in Fig. 10. Also listed in Table VIII are equations derived by least-squares fitting of the Arrhenius equation to the data. The lines through the data points in Fig. 10 represent the equations. From the slopes of these lines, values of the activation energy of 9.1, 9.8, $9.5,8.9$, and $8.5 \mathrm{kcal} / \mathrm{mole}$ were calculated for data obtained at 89,108 , 189,241 , and 369 Torr, respectively.

TABLE VIII Reaction Rate Constants, $\mathrm{k}^{\prime}$ for $\mathrm{U}_{3} \mathrm{O}_{8}-\mathrm{BrF}_{5}$ Reaction

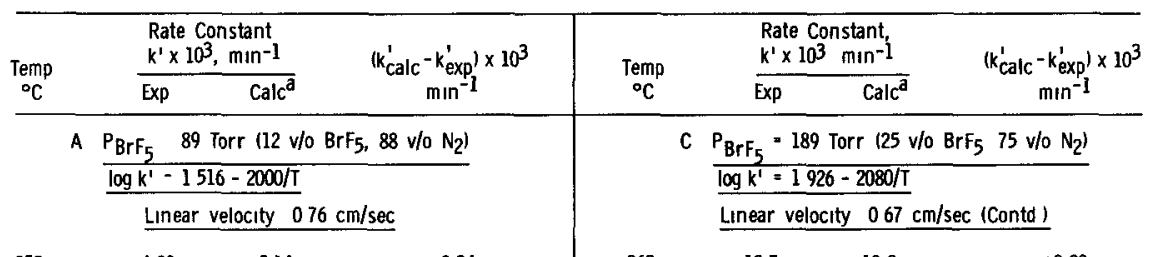

$\begin{array}{llll}252 & 480 & 514 & +034 \\ 267 & 704 & 656 & -048 \\ 278 & 860 & 778 & -082 \\ 313 & 103 & 128 & +250 \\ 327 & 163 & 154 & -090 \\ 358 & 235 & 224 & -110\end{array}$

B $\mathrm{P}_{\mathrm{BrF}_{5}}-108$ Torr $\left(14 \mathrm{v} / 0 \mathrm{BrF}_{5} 86 \mathrm{v} / \mathrm{O} \mathrm{N}_{2}\right)$ $\log k^{1} \quad 1892-2130 / T$ Linear velocity $061 \mathrm{~cm} / \mathrm{sec}$

$\begin{array}{lccc}253 & 710 & 688 & -022 \\ 261 & 840 & 792 & -048 \\ 275^{\mathrm{b}} & 955 & 100 & +045 \\ 276^{\mathrm{C}} & 966 & 100 & +034 \\ 277 & 967 & 103 & +063 \\ 298 & 140 & 144 & +040 \\ 316 & 184 & 187 & +030 \\ 329 & 227 & 224 & -030\end{array}$

C $\mathrm{P}_{\mathrm{BrF}_{5}} 189$ Torr $\left(25 \mathrm{v}^{\circ} \quad \mathrm{BrF}_{5} \quad 75\right.$ v/o $\left.\mathrm{N}_{2}\right)$ $\log k^{\prime}$ I 926-2080/T Linear velocity $067 \mathrm{~cm} / \mathrm{sec}$

$\begin{array}{llll}243 & 803 & 782 & -021 \\ 243^{d} & 790 & 782 & -008 \\ 244 & 770 & 796 & +026\end{array}$

$\begin{array}{llll}262 & 107 & 109 & +020 \\ 278 & 151 & 141 & -100 \\ 286 & 145 & 160 & +150 \\ 301 & 204 & 200 & -040 \\ 302 & 207 & 203 & -040\end{array}$

D $\mathrm{P}_{\mathrm{BrF}}=241$ Torr $\left(32 \mathrm{v} / 0 \mathrm{BrF}_{5} 68 \mathrm{v} / 0 \mathrm{~N}_{2}\right)$ $\log k^{\prime}=1809-1940 / T$ Linear velocity $064 \mathrm{~cm} / \mathrm{sec}$

$\begin{array}{rrrr}226 & 844 & 848 & +004 \\ 252 & 132 & 132 & 000 \\ 257 & 149 & 143 & -060 \\ 278 & 187 & 197 & +100 \\ 302 & 282 & 276 & -060\end{array}$

E $\mathrm{P}_{\mathrm{BrF}_{5}}-369$ Torr $\left(49 \mathrm{v} / \mathrm{O} \mathrm{BrF}_{5}, 51 \mathrm{v} / 0 \mathrm{~N}_{2}\right)$ $\log k^{\prime}=1813-1860 / T$ Linear velocity $067 \mathrm{~cm} / \mathrm{sec}$

alues in this column were calculated by use of equations in headings A B C, D and $E$

bisnear velocity of gas phase $192 \mathrm{~cm} / \mathrm{sec}$

CLinear velocity of gas phase $128 \mathrm{~cm} / \mathrm{sec}$

dLInear velocity of gas phase $131 \mathrm{~cm} / \mathrm{sec}$

Eunear velocity of gas phase $088 \mathrm{~cm} / \mathrm{sec}$

Linear velocity of gas phase $043 \mathrm{~cm} / \mathrm{sec}$

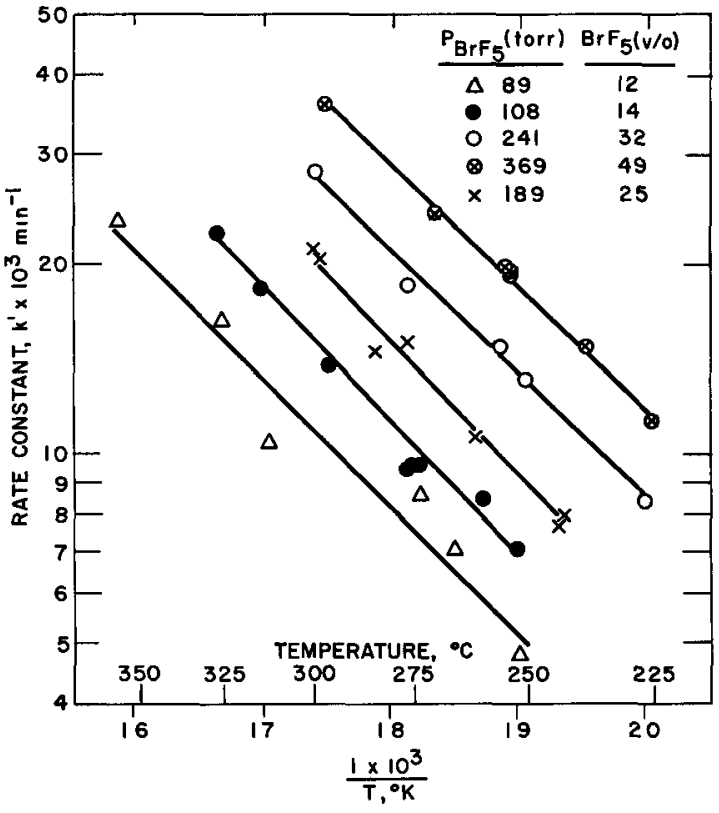

Fig. 10

Temperature Dependence of Rate Constant for $\mathrm{U}_{3} \mathrm{O}_{8}-\mathrm{BrF}_{5}$ Reaction 
Values of the rate constant at selected temperatures, calculated using the equations listed in Table VIII, are plotted in Fig. 11 as log $\mathrm{k}^{\prime}$ versus the log of the $\mathrm{BrF}_{5}$ partial pressure. Values of the pressure dependence

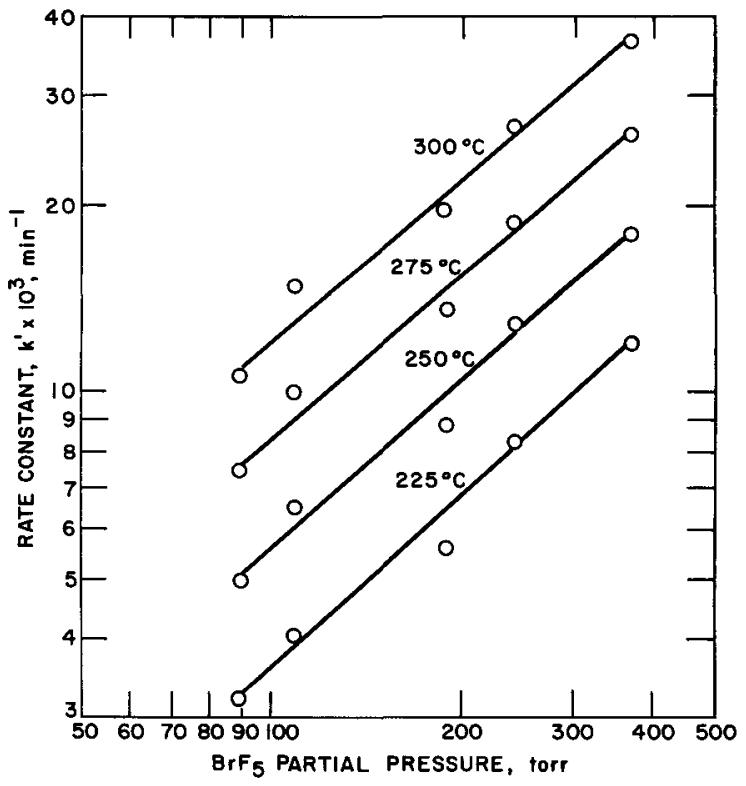

$308-99$

Fig. 11. Effect of $\mathrm{BrF}_{5}$ Partial Pressure on Rate Constant for $\mathrm{U}_{3} \mathrm{O}_{8}-\mathrm{BrF}_{5}$ Reaction of the reaction were calculated from the slopes of the plots of Fig. 11 and ranged in value from 0.87 to 0.93 with an average value of 0.90 . From these data, the following equation was derived for the combined temperature and pressure dependence of the $\mathrm{U}_{3} \mathrm{O}_{8-}$ $\mathrm{BrF}_{5}$ reaction:

$$
\begin{aligned}
\log k^{\prime} & =0.90 \log P_{B r F_{5}} \text { (Torr) } \\
& -2000 / \mathrm{T}\left({ }^{\circ} \mathrm{K}\right)-0.220 .
\end{aligned}
$$

A value of $9.2 \mathrm{kcal} / \mathrm{mole}$ was calculated for the activation energy for the combined data.

The activation energy for the $\mathrm{U}_{3} \mathrm{O}_{8}-\mathrm{BrF}_{5}$ reaction falls between the value of $21.3 \mathrm{kcal} / \mathrm{mole}$ for the reaction of $\mathrm{U}_{3} \mathrm{O}_{8}$ with fluorine ${ }^{24}$ and the value of approximately $1 \mathrm{kcal} / \mathrm{mole}$ for the reaction of $\mathrm{U}_{3} \mathrm{O}_{8}$ with $\mathrm{BrF}_{3}{ }^{16}$ The pressure dependence of all these reactions is approximately first order. In contrast to the $\mathrm{U}_{3} \mathrm{O}_{8}-\mathrm{BrF}_{3}$ reaction, the $\mathrm{U}_{3} \mathrm{O}_{8}-\mathrm{BrF}{ }_{5}$ reaction did not exhibit a minimum in the temperature dependence of the rate constant.

Experiments were performed to determine the effect of different linear velocities of the gas phase on the reaction rate constant for the $\mathrm{U}_{3} \mathrm{O}_{8}-\mathrm{BrF}_{5}$ reaction. Three sets of experiments were performed at $\mathrm{BrF}{ }_{5}$ partial pressures of 108, 189, and 369 Torr, and the results are listed in Table IX. These results indicate that the effect of linear velocity of the gas phase on the rate constant is negligible.

TABLE IX. Effect of Linear Velocity of Gas Phase on Reaction Rate Constant for $\mathrm{U}_{3} \mathrm{O}_{8}-\mathrm{BrF}_{5}$ Reaction

Total system pressure: 760 Torr

\begin{tabular}{|c|c|c|c|c|c|c|c|c|}
\hline $\begin{array}{c}\text { Reaction } \\
\text { Temp, } \\
{ }^{\circ} \mathrm{C}\end{array}$ & $\begin{array}{l}\text { Linear } \\
\text { Velocity, } \\
\mathrm{cm} / \mathrm{sec}\end{array}$ & $\begin{array}{l}\text { Rate Constant } \\
k^{\prime} \times 10^{3}, \min ^{-1}\end{array}$ & $\begin{array}{l}\text { Reaction } \\
\text { Temp, } \\
{ }^{\circ} \mathrm{C}\end{array}$ & $\begin{array}{c}\text { Linear } \\
\text { Velocity, } \\
\mathrm{cm} / \mathrm{sec}\end{array}$ & $\begin{array}{l}\text { Rate Constant } \\
k^{\prime} \times 10^{3}, \min ^{-1}\end{array}$ & $\begin{array}{c}\text { Reaction } \\
\text { Temp, } \\
{ }^{\circ} \mathrm{C}\end{array}$ & $\begin{array}{l}\text { Linear } \\
\text { Velocity, } \\
\mathrm{cm} / \mathrm{sec}\end{array}$ & $\begin{array}{l}\text { Rate Constant, } \\
k^{1} \times 10^{3}, \min ^{-1}\end{array}$ \\
\hline A. $\mathrm{P}_{\mathrm{BrF}_{5}}$ & Torr (14 & $\mathrm{BrF}_{5}, 86$ v/o $\left.\mathrm{N}_{2}\right)$ & \multicolumn{3}{|c|}{ B. $\mathrm{P}_{\mathrm{BrF}_{5}}=189$ Torr $\left(25 \mathrm{v} / 0 \mathrm{BrF}_{5}, 75 \mathrm{v} / 0 \mathrm{~N}_{2}\right)$} & \multicolumn{3}{|c|}{ C. $\mathrm{P}_{\mathrm{BrF}_{5}}=369$ Torr $\left(49 \mathrm{v} / 0 \mathrm{BrF}_{5}, 51\right.$ v/0 N $\mathrm{N}_{2}$} \\
\hline $\begin{array}{l}277 \\
276 \\
275\end{array}$ & $\begin{array}{l}0.61 \\
1.28 \\
1.92\end{array}$ & $\begin{array}{l}9.67 \\
9.66 \\
9.55\end{array}$ & $\begin{array}{l}243 \\
243\end{array}$ & $\begin{array}{l}0.67 \\
1.31\end{array}$ & $\begin{array}{l}8.03 \\
7.90\end{array}$ & $\begin{array}{l}256 \\
255 \\
254\end{array}$ & $\begin{array}{l}0.43 \\
0.67 \\
0.88\end{array}$ & $\begin{array}{l}20.0 \\
19.6 \\
19.3\end{array}$ \\
\hline
\end{tabular}

Quantity of $\mathrm{U}_{3} \mathrm{O}_{8}$ used: $300 \mathrm{mg}$ 
By analogy to the $\mathrm{U}_{3} \mathrm{O}_{8}$-fluorine reaction, the reaction between $\mathrm{U}_{3} \mathrm{O}_{8}$ and $\mathrm{BrF}_{5}$ is considered to proceed according to the following equations:

$$
\begin{aligned}
& 5 \mathrm{U}_{3} \mathrm{O}_{8}+6 \mathrm{BrF} 5=15 \mathrm{UO}_{2} \mathrm{~F}_{2}+3 \mathrm{Br}_{2}+5 \mathrm{O}_{2} ; \\
& 5 \mathrm{UO}_{2} \mathrm{~F}_{2}+4 \mathrm{BrF} \mathrm{F}_{5}=5 \mathrm{UF}_{6}+2 \mathrm{Br}_{2}+5 \mathrm{O}_{2} .
\end{aligned}
$$

In addition, as reported by Rampy, ${ }^{26} \mathrm{U}_{3} \mathrm{O}_{8}$ reacts with $\mathrm{UF}_{6}$ to form $\mathrm{UO}_{2} \mathrm{~F}_{2}$ and $\mathrm{UF}_{4}$ as shown in the following equation:

$$
\mathrm{U}_{3} \mathrm{O}_{8}+2 \mathrm{UF}_{6}=4 \mathrm{UO}_{2} \mathrm{~F}_{2}+\mathrm{UF}_{4} \text {. }
$$

Evidence for the reaction between $\mathrm{U}_{3} \mathrm{O}_{8}$ and $\mathrm{UF}_{6}$ was obtained from boatreactor experiments, which will be described later in this section.

In Eqs. 13 and 14, bromine is given as a reaction product of the $\mathrm{BrF}_{5}$ component of the reaction. This was verified by fluorine titration $^{19}$ of the bromine in the condensed reaction products. Determination of the bromine content of the condensed products from five experiments resulted in an average value of $102 \pm 4 \%$ of the stoichiometric quantity of bromine; individual values ranged from 94 to $108 \%$. The stoichiometric quantity of bromine was calculated from the fraction of $\mathrm{U}_{3} \mathrm{O}_{8}$ converted to $\mathrm{UF}_{6}$ in each experiment, based on the stoichiometry of Reactions 10 and 11.

The analytical method was tested by titrating synthetic reaction product mixtures containing only bromine and $\mathrm{BrF}_{5}$. The quantity of bromine added to the $\mathrm{BrF}_{5}$ was determined from PVT relationships. Three synthetic mixtures were titrated and resulted in an average value of $100 \pm$ $6 \%$ of the theoretical amount of bromine, with individual values of 94,97 , and $108 \%$. These results show that the $\mathrm{U}_{3} \mathrm{O}_{8}-\mathrm{BrF}_{5}$ reaction data fall within the precision of the analytical method, and indicate that bromine is the only bromine-bearing product of the reaction.

Evidence that $\mathrm{U}_{3} \mathrm{O}_{8}$ and the product $\mathrm{UF}_{6}$ react to form a watersoluble uranium species was obtained from preliminary boat-reactor experiments over the range $250-400^{\circ} \mathrm{C}$. About $5 \mathrm{~g}$ of $\mathrm{U}_{3} \mathrm{O}_{8}$ were used in each experiment. The gas phase contained $26 \mathrm{v} / 0 \mathrm{BrF}_{5}$ and $74 \mathrm{v} / 0$ nitrogen at a total flow rate of $250 \mathrm{ml} / \mathrm{min}$, corresponding to a linear gas velocity in the reactor of $1.22 \mathrm{~cm} / \mathrm{sec}$. The extent of reaction, i.e., conversion of $\mathrm{U}_{3} \mathrm{O}_{8}$ to $\mathrm{UF}_{6}$ in an experiment, was calculated from the weight change of the solid. In some cases, this method for calculating the fraction reacted was checked by uranium analysis of the residues; agreement in all cases was excellent. Figure 12 shows the relationship between $(1-F)^{1 / 3}$ and the reaction time at several reaction temperatures. At reaction temperatures of $300^{\circ} \mathrm{C}$ or greater, the plots show a change in slope, indicating an increase in the rate of uranium conversion to $\mathrm{UF}_{6}$ with increasing reaction time. 


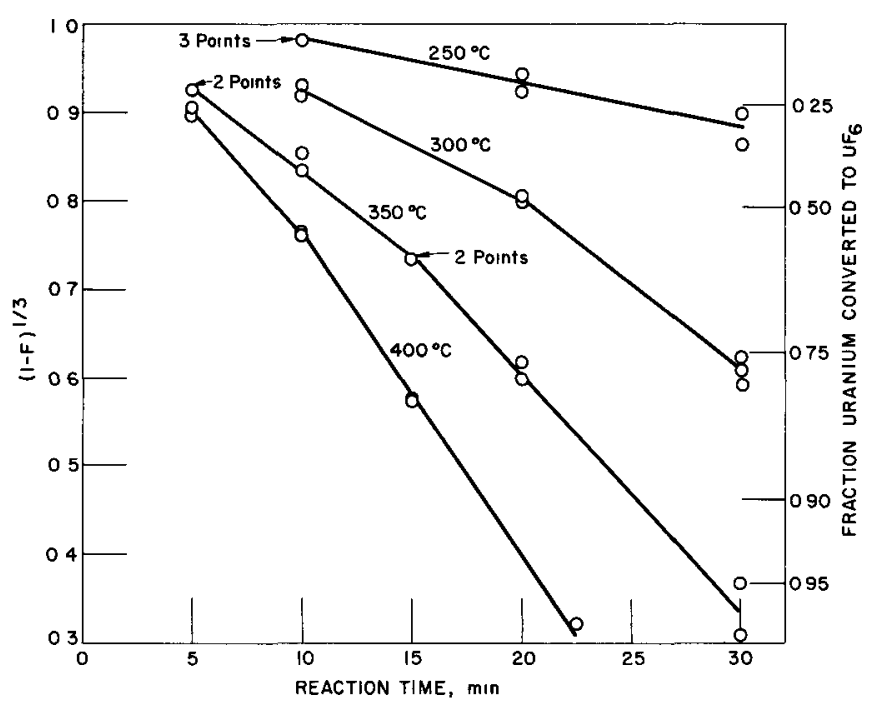

$108-9295$

Fig. 12. Plots of $(1-F)^{1 / 3}$ vs. Reaction Time, $t$, for Range $250-400^{\circ} \mathrm{C}$ for $\mathrm{U}_{3} \mathrm{O}_{8}-\mathrm{BrF}_{5}$ Reaction
Chemical analyses of the reaction residues for total uranium and water-soluble uranium suggested that the residues were composed of $\mathrm{U}_{3} \mathrm{O}_{8}$ and $\mathrm{UO}_{2} \mathrm{~F}_{2}$. However, X-ray diffraction analyses of the residues indicated the presence of $\mathrm{U}_{3} \mathrm{O}_{8}$ and an unidentified phase, which was not $\mathrm{UO}_{2} \mathrm{~F}_{2}, \mathrm{UF}_{4}$, a uranium oxide, or a uranium bromide. (Chemical analyses showed no indication of the presence of bromine in the reaction residues.) The fraction of the reaction residue that was water soluble increased both with reaction time at a given temperature and with temperature at a given reaction time

(as shown in Fig. 13). However, even after conversion of $97 \%$ of the uranium to $\mathrm{UF}_{6}$, most of the residue was still $\mathrm{U}_{3} \mathrm{O}_{8}$, the water-soluble fraction of the residue constituting only about $20 \%$. Since the unidentified phase could not be characterized, subsequent discussion of the mechanism assumes that all of the watersoluble uranium is " $\mathrm{UO}_{2} \mathrm{~F}_{2}$." Rampy $^{26}$ indicated that the reaction of $\mathrm{U}_{3} \mathrm{O}_{8}$ and $\mathrm{UF}_{6}$ is not simple but may involve undefined intermediates. It is not surprising to find no $\mathrm{UF}_{4}$ in the residues, considering the high reaction rate that could be expected for the $\mathrm{UF}_{4}-\mathrm{BrF}_{5}$ reaction at these temperatures. (See the plot of temperature dependence of rate for $\mathrm{UF}_{4}-\mathrm{BrF}_{5}$ reaction in Fig. 7.)

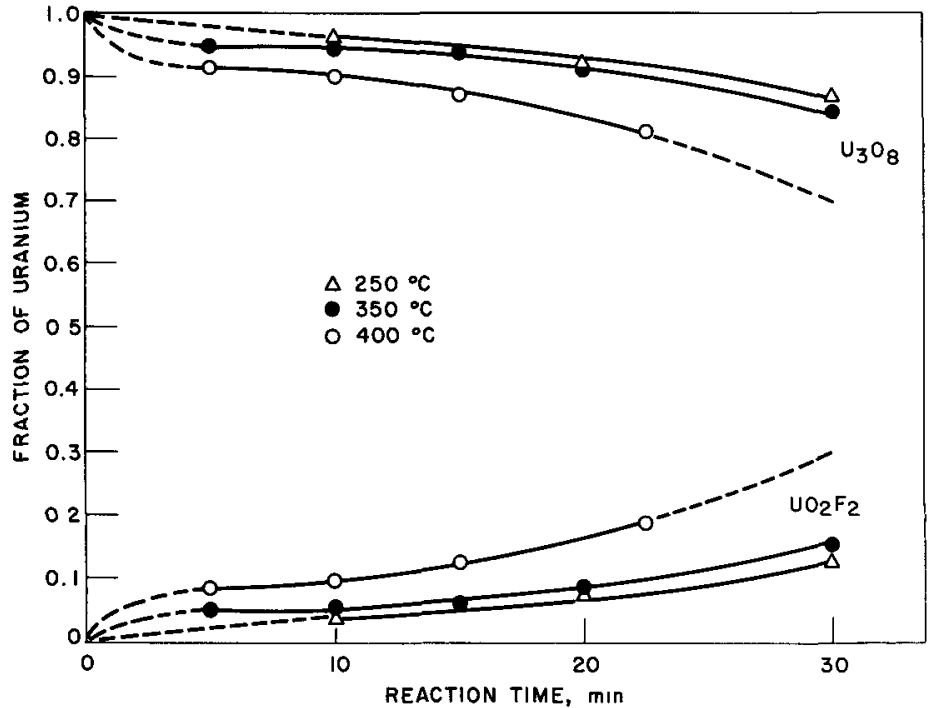

108-9285 Rev. 1

Fig. 13 Fraction of Solid Residue Present as $\mathrm{U}_{3} \mathrm{O}_{8}$ and $\mathrm{UO}_{2} \mathrm{~F}_{2}$ for $\mathrm{U}_{3} \mathrm{O}_{8}-\mathrm{BrF}_{5}$ Reaction

The rate behavior observed for the $\mathrm{U}_{3} \mathrm{O}_{8}-\mathrm{BrF}_{5}$ reaction suggests the occurrence of a concomitant reaction. This reaction initially hinders the production or volatilization of $\mathrm{UF}_{6}$, but its effect is diminished after a period of time and then leads to higher rates of production or volatilization of $\mathrm{UF}_{6}$. During the initial, lower-rate portion of the reaction, 
which was observed at $300-400^{\circ} \mathrm{C}$ and constituted the entire observed reaction period at $250^{\circ} \mathrm{C}$, the interaction of $\mathrm{UF}_{6}$ with $\mathrm{U}_{3} \mathrm{O}_{8}$ reduces the extent of volatilization of $\mathrm{UF}_{6}$; a layer of $\mathrm{UO}_{2} \mathrm{~F}_{2}$ forms on the $\mathrm{U}_{3} \mathrm{O}_{8}$ particles. This process continues until the thickness of the $\mathrm{UO}_{2} \mathrm{~F}_{2}$ layer begins to act as an effective diffusion barrier to the reaction between $\mathrm{UF}_{6}$ and $\mathrm{U}_{3} \mathrm{O}_{8}$. At this time, indicated by the breaks in the plots of Fig. 12 at $300-400^{\circ} \mathrm{C}$, further production of $U_{F}$ results in greater volatilization of $U F_{6}$ and in a

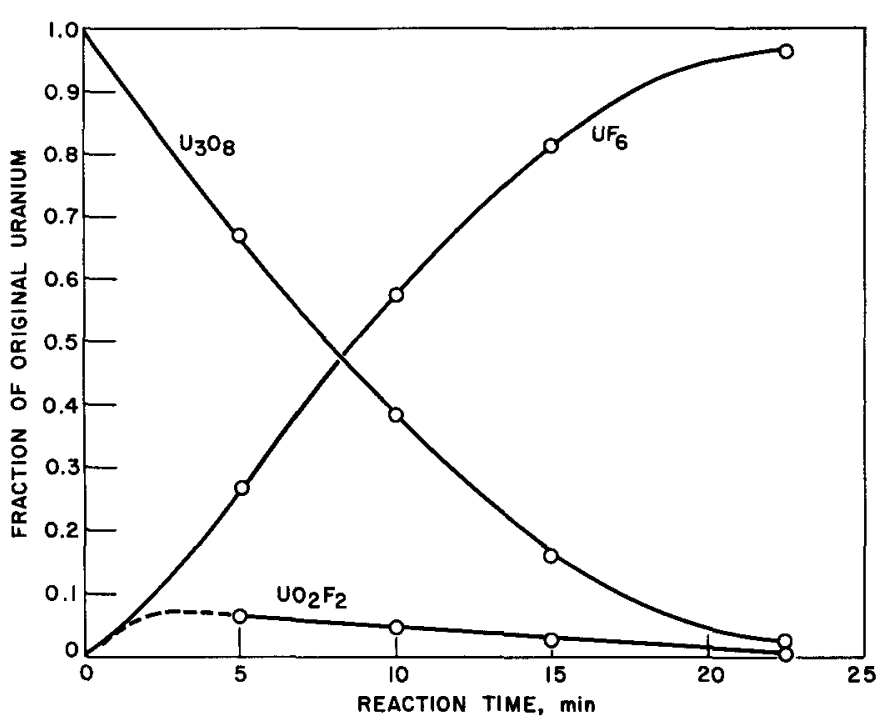

$108-9288$

Fig. 14. Distribution of Original Uranium as $\mathrm{UO}_{2} \mathrm{~F}_{2}$ and $\mathrm{U}_{3} \mathrm{O}_{8}$ in Reaction Residues and as Volatilized $\mathrm{UF}_{6}$ for $\mathrm{U}_{3} \mathrm{O}_{8}-\mathrm{BrF}_{5}$ Reaction at $400^{\circ} \mathrm{C}$ marked increase in the rate of the reaction. The shorter times required for the change in rate to occur at higher temperatures (see Fig. 12) appear to support this proposed reaction mechanism. At higher temperatures and hence increased reaction rates, the buildup of $\mathrm{UO}_{2} \mathrm{~F}_{2}$ on the solid reactant should occur more quickly. Although the fraction of the original uranium present as $\mathrm{UO}_{2} \mathrm{~F}_{2}$ in the solid residues decreases with reaction time (as shown in Fig. 14 for the reaction at $400^{\circ} \mathrm{C}$ ), the fraction of $\mathrm{UO}_{2} \mathrm{~F}_{2}$ in the residue increases with both reaction time and temperature (as shown in Fig. 13).

The absence of a break in the reaction rate at $250^{\circ} \mathrm{C}$ can be explained on the basis of generally lower reaction rates. Figure 15 shows the fractions of the original uranium present as $\mathrm{U}_{3} \mathrm{O}_{8}$ and $\mathrm{UO}_{2} \mathrm{~F}_{2}$ in the solid

\section{Fig. 15}

Distribution of Original Uranium as $\mathrm{UO}_{2} \mathrm{~F}_{2}$ and $\mathrm{U}_{3} \mathrm{O}_{8}$ in Reaction Residues and as Vola tilized $\mathrm{UF}_{6}$ for $\mathrm{U}_{3} \mathrm{O}_{8}-\mathrm{BrF}_{5}$ Reaction at $250^{\circ} \mathrm{C}$

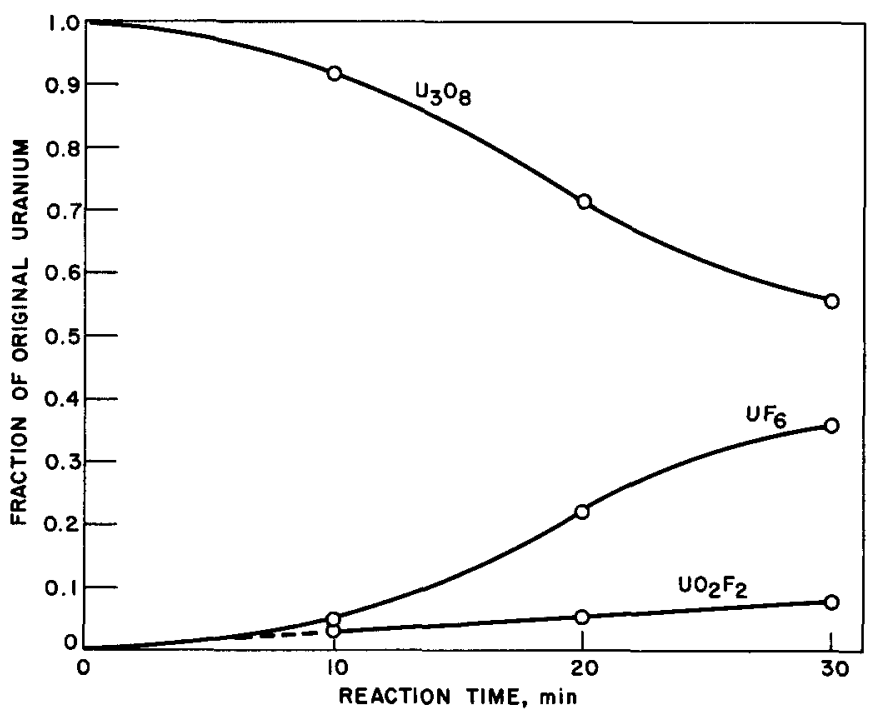


residue and as volatilized $\mathrm{UF}_{6}$. These plots show a greatly reduced rate of production of $\mathrm{UF}_{6}$ and a steady buildup of $\mathrm{UO}_{2} \mathrm{~F}_{2}$ in the residues, when compared with similar plots (Fig. 14) for the reaction at $400^{\circ} \mathrm{C}$. These results lead to the conclusion that at $250^{\circ} \mathrm{C}$ a reaction time of $30 \mathrm{~min}$ was not sufficient to allow the change in rate to occur. The similar behavior in the accumulation of $\mathrm{UO}_{2} \mathrm{~F}_{2}$ in the reaction residues (plotted in Fig. 13) suggests that there is no change in the reaction mechanism with changing temperature.

\section{4. $\mathrm{UO}_{2}-\mathrm{BrF}_{5}$ Reaction}

The reaction of $\mathrm{UO}_{2}$ with $\mathrm{BrF}_{5}$ proceeds by the formation of $\mathrm{UO}_{2} \mathrm{~F}_{2}$, which, in turn, is fluorinated to $\mathrm{UF}_{6}$. Experiments were performed at $224-302^{\circ} \mathrm{C}$ for $\mathrm{ANL} \mathrm{UO}_{2}$ and at $307-367^{\circ} \mathrm{C}$ for $\mathrm{NUMEC} \mathrm{UO}_{2}$. The partial pressure of $\mathrm{BrF}_{5}$ in the gas phase $\left(26 \mathrm{v} / 0 \mathrm{BrF}_{5}, 74 \mathrm{v} / 0\right.$ nitrogen) was 181 Torr, and the linear velocity of the gas phase was about $0.7 \mathrm{~cm} / \mathrm{sec}$. The rate constants obtained are listed in Table $X$ and are shown as a function of reciprocal temperature in Fig. 16. The products of the reaction are assumed to be $\mathrm{UF}_{6}$ and $\mathrm{O}_{2}$, together with elemental bromine. This assumption is in agreement with the stolchiometry previously discussed for the reactions with $\mathrm{UF}_{4}$ and $\mathrm{U}_{3} \mathrm{O}_{8}$. From least-squares fits of the Arrhenius equation to the two sets of data, the following equations were obtained:

$$
\begin{aligned}
& \mathrm{ANL} \mathrm{UO}_{2}: \log \mathrm{k}^{\prime}=1.493-\frac{\mathrm{l} 630}{\mathrm{~T}}: \\
& \text { NUMEC UO} \\
& \text { : } \log \mathrm{k}^{\prime}=3.441-\frac{3060}{\mathrm{~T}} .
\end{aligned}
$$

TABLE X Reaction Rate Constants, $\mathrm{k}^{\prime}$ for $\mathrm{U0}_{2}-\mathrm{BrF}_{5}$ Reaction

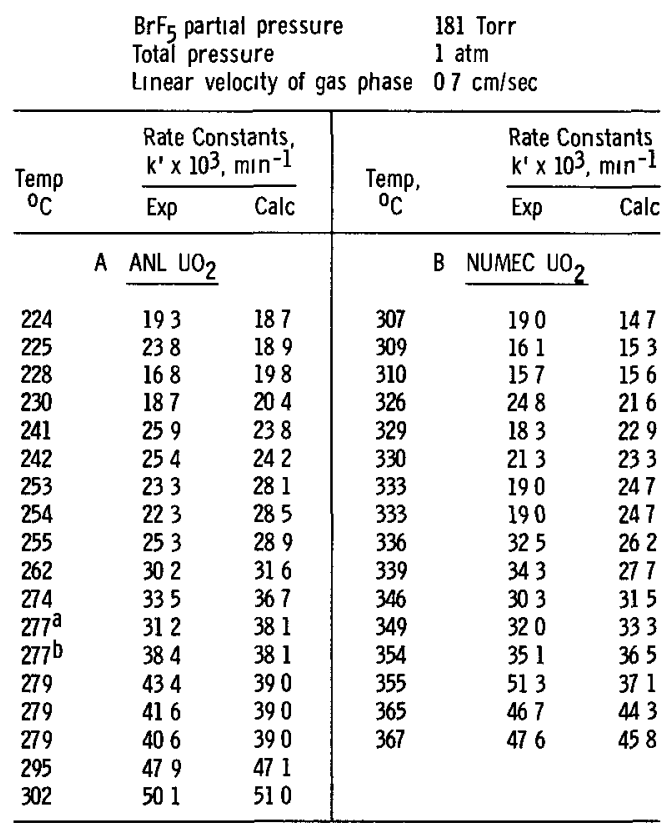

aLInear velocity $=085 \mathrm{~cm} / \mathrm{sec}$

bLinear velocity - $125 \mathrm{~cm} / \mathrm{sec}$

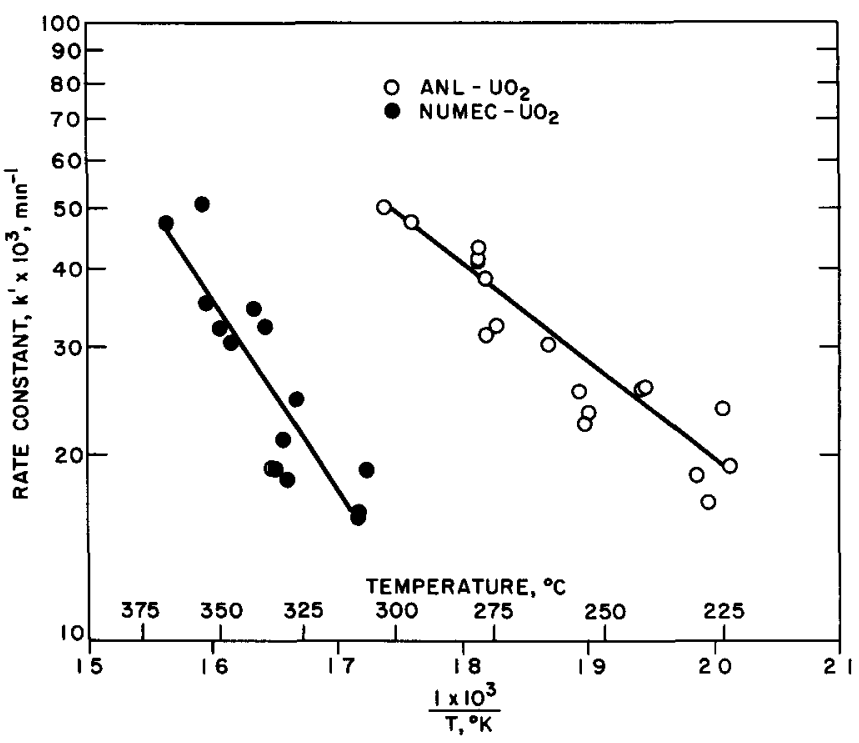

$308-531$

F1g. 16. Temperature Dependence of Rate Constants for $\mathrm{UO}_{2}-\mathrm{BrF}_{5}$ Reaction $\left(\mathrm{P}_{\mathrm{BrF}_{5}}=181\right.$ Torr $)$ 
From these equations, activation energies of 7.5 and $14 \mathrm{kcal} / \mathrm{mole}$ were calculated for the ANL and NUMEC materials, respectively.

The activation energy of $7.5 \mathrm{kcal} / \mathrm{mole}$ for the $\mathrm{ANL} \mathrm{UO}_{2}$ sug gests that the reaction is controlled by the formation of $\mathrm{UO}_{2} \mathrm{~F}_{2}$ and depletion of $\mathrm{UO}_{2} \mathrm{~F}_{2}$ by fluorination. The activation energy for the $\mathrm{UO}_{2} \mathrm{~F}_{2}$ reaction is $8.3 \mathrm{kcal} / \mathrm{mole}$. For the NUMEC UO $\mathrm{NO}_{2}$, the value of $14 \mathrm{kcal} / \mathrm{mole}$ suggests the presence of $\mathrm{UF}_{4}$ as well as $\mathrm{UO}_{2} \mathrm{~F}_{2}$ on the surface of the reacting particles, since the activation energy for the $\mathrm{UF}_{4}$ reaction is $16.9 \mathrm{kcal} / \mathrm{mole}$. Rampy ${ }^{26}$ has shown that both $\mathrm{UO}_{2} \mathrm{~F}_{2}$ and $\mathrm{UF}_{4}$ are produced by the reaction of $\mathrm{UF}_{6}$ with $\mathrm{UO}_{2}$. Therefore, if in the reaction of NUMEC UO $\mathrm{U}_{2}$, the product $\mathrm{UF}_{6}$ reacts with the $\mathrm{UO}_{2}$, the solid surface would be an equimolar mixture of $\mathrm{UO}_{2} \mathrm{~F}_{2}$ and $\mathrm{UF}_{4}$. For such an equimolar mixture, an estimate of the activation energy $(0.5 \times 8.3+0.5 \times 16.9)$ results in a value of $12.6 \mathrm{kcal} / \mathrm{mole}$, in reasonable agreement with the value of $14 \mathrm{kcal} / \mathrm{mole}$ obtained experimentally. Reasonable agreement of theoretical with experimental activation energies had been previously obtained for $(2 / 3) \mathrm{UO}_{2} \mathrm{~F}_{2}-(1 / 3) \mathrm{UF}_{4}$ mixtures (see Fig. 4).

The difference in behavior of the two types of oxide probably arises from different degrees of reactivity of the two oxides. A high reactivity of $\mathrm{ANL} \mathrm{UO}_{2}$ may result in rapid conversion of the surface of the solid to $\mathrm{UO}_{2} \mathrm{~F}_{2}$, so that interaction at the oxide surface with $\mathrm{UF}_{6}$ to form a mixture of $\mathrm{UF}_{4}$ and $\mathrm{UO}_{2} \mathrm{~F}_{2}$ would be essentially absent. Sintered oxide (NUMEC $\mathrm{UO}_{2}$ ) is more slowly fluorinated to $\mathrm{UO}_{2} \mathrm{~F}_{2}$, and therefore some oxide surface is available for contact with $\mathrm{UF}_{6}$ to form $\mathrm{UF}_{4}$ and $\mathrm{UO}_{2} \mathrm{~F}_{2}$. To obtain rates comparable to those obtained for $\mathrm{ANL} \mathrm{UO}_{2}$, higher temperatures are needed for NUMEC $\mathrm{UO}_{2}$; this can be ascribed to the lower reactivity of the sintered $\mathrm{UO}_{2}$ particles.

Experiments were also performed, using ANL $\mathrm{UO}_{2}$, to determine the dependence of the reaction rate on the $\mathrm{BrF}_{5}$ partial pressure and the linear velocity of the gas phase. The two experiments (at $277^{\circ} \mathrm{C}$ in Part $\mathrm{A}$ of Table $X)$ were performed at linear velocities of 0.85 and $1.25 \mathrm{~cm} / \mathrm{sec}$. Values of the rate constant of 0.0312 and $0.0384 \mathrm{~min}^{-1}$ obtained for these experiments indicate a small effect of the linear velocity of the gas phase on the value of the rate constant. Other experiments were performed in which the $\mathrm{BrF}_{5}$ partial pressure in the gas phase was 74 or 369 Torr. The values of the rate constant obtained, along with those for reactions at 181 Torr $\mathrm{BrF}_{5}$ partial pressure (from Table X), are listed in Part A of Table XI. From these data a value of 0.84 was derived for the coefficient, $n$, of the pressure term in the equation $k^{\prime}=A e^{-E} / R^{T} P^{n}$. Combining this value of $\mathrm{n}$ with the equation for the temperature dependence of the $\mathrm{ANL} \mathrm{UO}_{2}-\mathrm{BrF}_{5}$ reaction resulted in the following equation representing the temperature and pressure dependence of the $\mathrm{UO}_{2}-\mathrm{BrF}_{5}$ reaction:

$$
\log k^{\prime}=0.84 \log P-\frac{1630}{T}-0.270 \text {, }
$$

where $P$ is expressed in Torr. 
TABLE XI Effect of $\mathrm{BrF}_{5}$ Partial Pressure for Reactions with $\mathrm{UO}_{2}$ and $\mathrm{UO}_{3}$

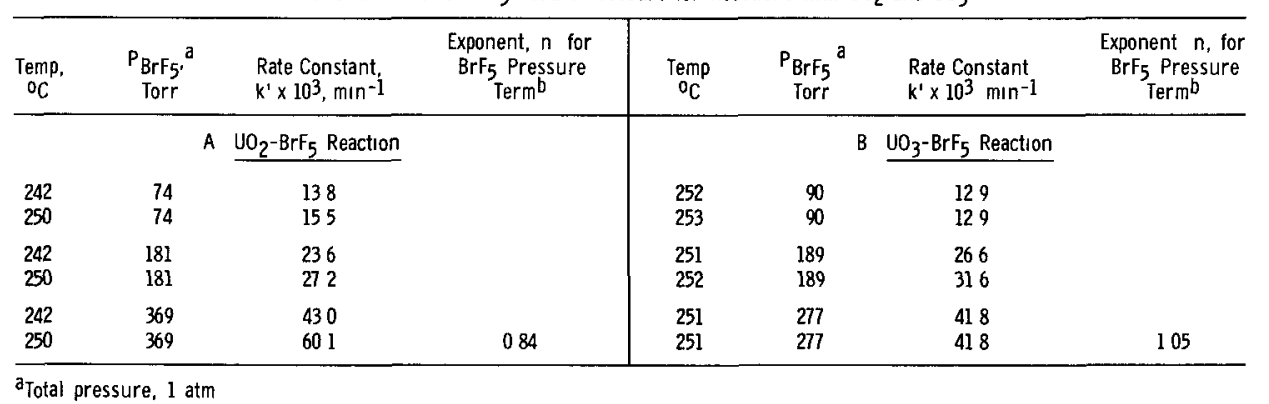

bFor equation $k^{\prime}=A e^{-E / R T p n}$

\begin{tabular}{|c|c|c|c|c|c|}
\hline \multicolumn{6}{|c|}{$\begin{array}{c}\text { TABLE XII Reaction Rate Constants } k^{\prime} \\
\text { for } \mathrm{UO}_{3}-\mathrm{BrF}_{5} \text { Reaction }\end{array}$} \\
\hline & \multicolumn{3}{|c|}{$\begin{array}{ll}\mathrm{BrF}_{5} \text { partial pressure } & 1 \\
\text { Total pressure } & 1 \\
\text { Linear velocity of } & \\
\text { gas phase } & 0\end{array}$} & \multicolumn{2}{|c|}{$\begin{array}{l}189 \text { Torr } \\
1 \mathrm{~atm} \\
07 \mathrm{~cm} / \mathrm{sec}\end{array}$} \\
\hline \multirow{2}{*}{$\begin{array}{l}\text { Temp. } \\
{ }^{\circ} \mathrm{C}\end{array}$} & \multicolumn{2}{|c|}{$\begin{array}{l}\text { Rate Constant, } \\
\mathbf{k}^{1} \times 10^{3} \mathrm{~min}^{-1} \\
\end{array}$} & \multirow{2}{*}{$\begin{array}{l}\text { Temp } \\
{ }^{\circ} \mathrm{C}\end{array}$} & \multicolumn{2}{|c|}{$\begin{array}{l}\text { Rate Constant } \\
\mathbf{k}^{\prime} \times 10^{3}, \mathrm{~min}^{-1}\end{array}$} \\
\hline & $\overline{\operatorname{Exp}}$ & Calc & & Exp & Calc \\
\hline 222 & 137 & 176 & 264 & 281 & 324 \\
\hline 226 & 177 & 187 & 265 & 286 & 328 \\
\hline 235 & 228 & 215 & 276 & 391 & 379 \\
\hline 236 & 228 & 218 & 278 & 404 & 389 \\
\hline 251 & 266 & 271 & 299 & 502 & 503 \\
\hline 252 & 316 & 275 & 300 & 516 & 509 \\
\hline 263 & 366 & 320 & & & \\
\hline
\end{tabular}

\section{5. $\mathrm{UO}_{3}-\mathrm{BrF}_{5}$ Reaction}

The kinetics of the $\mathrm{UO}_{3}-\mathrm{BrF}_{5}$ reaction were studied over the range 222 $300^{\circ} \mathrm{C}$. The $\mathrm{BrF}_{5}$ partial pressure was 189 Torr in a gas phase containing $27 \mathrm{v} / \mathrm{o}$ $\mathrm{BrF}_{5}$ and $73 \mathrm{v} / \mathrm{o}$ nitrogen at a linear velocity of about $0.7 \mathrm{~cm} / \mathrm{sec}$. The results are listed in Table XII and are shown in the plot of Fig. 17. The products of the reaction are assumed to be $\mathrm{UF}_{6}$ and $\mathrm{O}_{2}$, together with elemental bromine. The following equation representing the temperature dependence of the rate constant was obtained by a least-squares fit of the Arrhenius equation to the data:

$$
\log \mathrm{k}^{\prime}=1.636-\frac{1680}{\mathrm{~T}}
$$

A value of $7.7 \mathrm{kcal} / \mathrm{mole}$ was calculated for the activation energy of the $\mathrm{UO}_{3}-\mathrm{BrF}_{5}$ reaction.

Several experiments were performed to determine the dependence of the reaction rate on the $\mathrm{BrF}_{5}$ partial pressure. The data obtained at partial pressures of 90, 189, and 277 Torr are listed in Part B of Table XI. From these data a value of 1.05 for the coefficient $n$ of the equation $k^{\prime}=A e^{-E / R T} P^{n}$ was calculated. Combining this value of $n$ with the previous equation resulted in the following equation representing the combined temperature and pressure dependence of the reaction:

$$
\log k^{\prime}=1.05 \log P-\frac{1680}{T}-0.767
$$

where $P$ is expressed in Torr.

6. Mechanisms of the $\mathrm{UO}_{2}-\mathrm{BrF}_{5}$ and $\mathrm{UO}_{3}-\mathrm{BrF} \mathrm{F}_{5}$ Reactions

Rampy ${ }^{27}$ has shown that interactions between $\mathrm{UF}_{6}$ and both $\mathrm{UO}_{3}$ and $\mathrm{UO}_{2}$ occur. It was therefore reasonable to postulate that the fluorination 


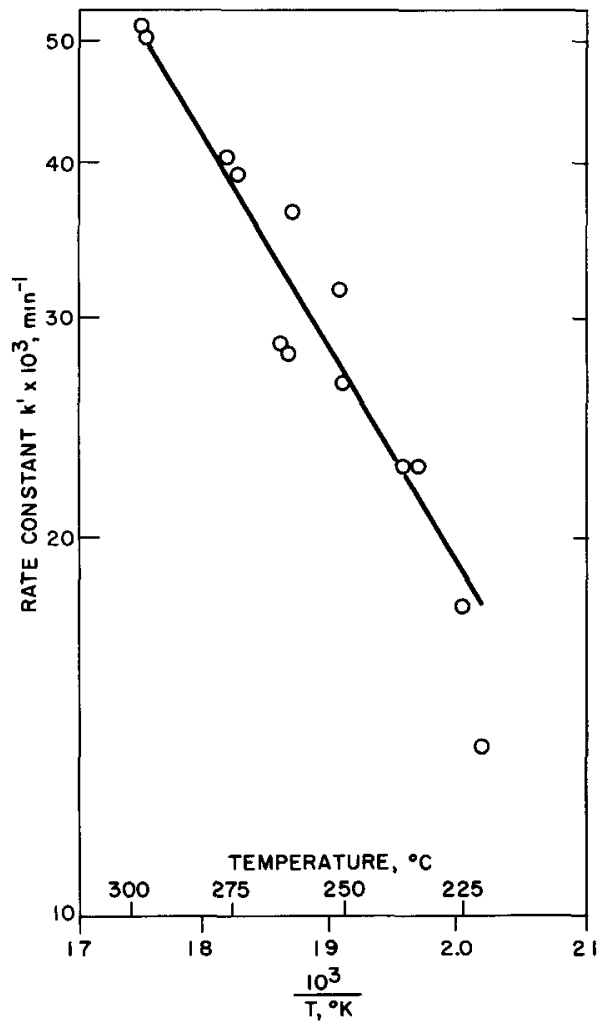

$308-411$

Fig. 17. Temperature Dependence of Rate Constants for $\mathrm{UO}_{3}-\mathrm{BrF}_{5}$ Reaction of these oxides using $\mathrm{BrF}_{5}$ would result in the same type of rate behavior as was obtained for the $\mathrm{U}_{3} \mathrm{O}_{8}-\mathrm{BrF}_{5}$ reaction. For the $\mathrm{UO}_{3}-\mathrm{BrF}_{5}$ reaction, the following reactions could be expected to occur:

$$
\begin{aligned}
& 5 \mathrm{UO}_{3}+2 \mathrm{BrF} F_{5} \rightarrow 5 \mathrm{UO}_{2} \mathrm{~F}_{2}+\mathrm{Br}_{2}+2 \frac{1}{2} \mathrm{O}_{2} ; \\
& 5 \mathrm{UO}_{2} \mathrm{~F}_{2}+4 \mathrm{BrF}_{5} \rightarrow 5 \mathrm{UF}_{6}+2 \mathrm{Br}_{2}+5 \mathrm{O}_{2} ; \\
& 2 \mathrm{UO}_{3}+\mathrm{UF}_{6} \rightarrow 3 \mathrm{UO}_{2} \mathrm{~F}_{2} .
\end{aligned}
$$

For the $\mathrm{UO}_{2}-\mathrm{BrF} F_{5}$ reaction, the following equations should apply:

$$
\begin{aligned}
& 5 \mathrm{UO}_{2}+4 \mathrm{BrF}_{5} \rightarrow 5 \mathrm{UF}_{4}+2 \mathrm{Br}_{2}+5 \mathrm{O}_{2} \\
& 5 \mathrm{UF}_{4}+2 \mathrm{BrF}_{5} \rightarrow 5 \mathrm{UF}_{6}+\mathrm{Br}_{2} \\
& \mathrm{UO}_{2}+\mathrm{UF}_{6} \rightarrow \mathrm{UO}_{2} \mathrm{~F}_{2}+\mathrm{UF}_{4} .
\end{aligned}
$$

In both these cases, the reaction between $\mathrm{UF}_{6}$ and the uranium oxide would result in a low initial rate of $\mathrm{UF}_{6}$ volatilization if the same mechanism as postulated for the $\mathrm{U}_{3} \mathrm{O}_{8}-\mathrm{BrF}_{5}$ reaction is applied. The rate of volatilization of $\mathrm{UF}_{6}$ would increase

when further interaction was hindered by the accumulation of a layer of $\mathrm{UO}_{2} \mathrm{~F}_{2}$ on the surface of the oxide particles.

Preliminary boat-reactor data for the reactions of $\mathrm{BrF}_{5}$ with $\mathrm{UO}_{3}$, $\mathrm{UO}_{2}$, and $\mathrm{U}_{3} \mathrm{O}_{8}$ at $300^{\circ} \mathrm{C}$ are compared in Fig. 18. These data show that both the $\mathrm{UO}_{3}-\mathrm{BrF}_{5}$ and the $\mathrm{UO}_{2}-\mathrm{BrF} \mathrm{F}_{5}$ reactions undergo a change in reaction rate similar to that observed for the $\mathrm{U}_{3} \mathrm{O}_{8}$ $\mathrm{BrF}_{5}$ reaction.

$X$ - ray diffraction analyses of the residue for the $\mathrm{UO}_{3}-\mathrm{BrF} \mathrm{F}_{5}$ reaction showed only the presence of $\mathrm{UO}_{3}$ and $\mathrm{UO}_{2} \mathrm{~F}_{2}$. For the $\mathrm{UO}_{2}-\mathrm{BrF}_{5}$ reaction, $\mathrm{X}$-ray diffraction analysis showed the presence of $\mathrm{UO}_{2}, \mathrm{UO}_{2} \mathrm{~F}_{2}, \mathrm{UF}_{4}$, and $\mathrm{U}_{3} \mathrm{O}_{8}$ in the residues. The $\mathrm{U}_{3} \mathrm{O}_{8}$ could be present as a result of oxidation of the $\mathrm{UO}_{2}$ by elemental oxygen, a reaction product.

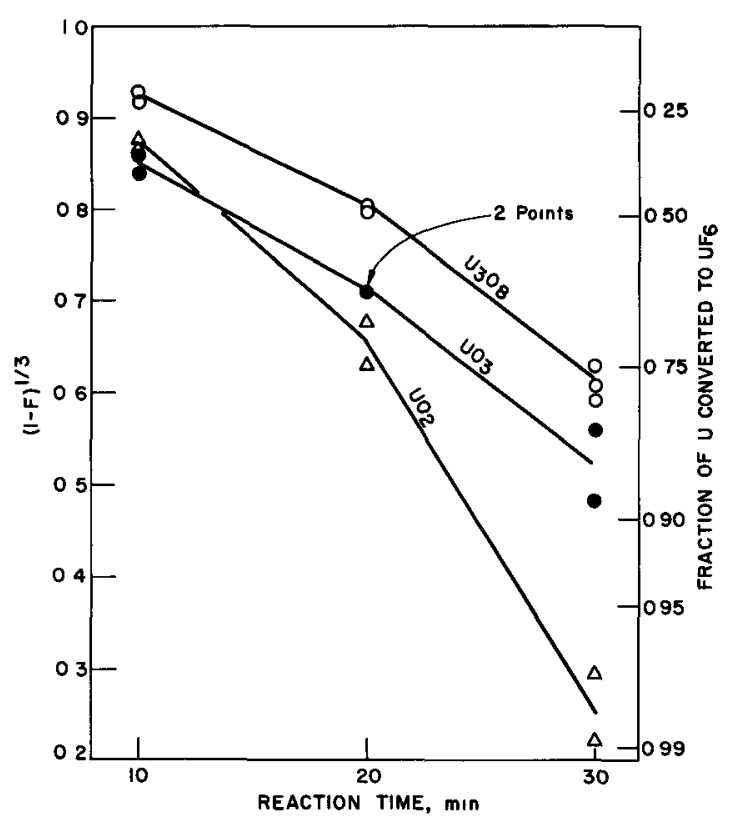

108-9274 Rev. 1

Fig. 18. Comparison of Reactions of $\mathrm{U}_{3} \mathrm{O}_{8}, \mathrm{UO}_{3}$, and $\mathrm{UO}_{2}$ with $\mathrm{BrF}_{5}$ at $300^{\circ} \mathrm{C}$ 


\section{Disposal of $\mathrm{BrF}_{5}$}

Several tests were performed to evaluate suitable methods for disposal of excess $\mathrm{BrF}_{5}$ from the laboratory experiments. Two solid materials were evaluated: commercial-grade activated alumina (8-14 mesh) and reagent-grade soda lime (4-8 mesh) which contained $7 \%$ water. The disposal experiments were performed by passing a $B r F_{5}-\mathrm{N}_{2}$ mixture through a 2 -in.diam, 6-in.-long trap containing a weighed amount of the solid disposal agent. Thermocouples to monitor the temperature of the disposal reaction were placed on the outside surface of the trap near the bottom, top, and center, and in a re-entrant well. The thermocouple in the well could be positioned from near the bottom of the solid bed to a point midway up the reaction vessel. A sodium hydroxide solution bubbler was placed downstream from the trap to indicate the breakthrough of bromine or $\mathrm{BrF}_{5}$.

In one experiment using activated alumina as the disposal agent, a feed stream consisting of $33 \mathrm{v} / \mathrm{O} \mathrm{BrF}_{5}$ and $67 \mathrm{v} / \mathrm{o}$ nitrogen was passed through a 4 -in.-deep bed at a flow of about $0.4 \mathrm{~g}$ of $\mathrm{BrF}_{5} / \mathrm{min}$. The reaction front was at $120^{\circ} \mathrm{C}$, and after $14 \mathrm{~g}$ of $\mathrm{BrF}_{5}$ had been passed through the reaction vessel bromine was noted in the effluent-gas stream. At this point in the reaction, the upper part of the reaction vessel was at $100^{\circ} \mathrm{C}$. The alumina removed from the reactor showed a narrow white band $\left(\mathrm{AlF}_{3}\right)$ at the bottom of the bed, indicating that reaction with the fluorine component of the $\mathrm{BrF}_{5}$ had occurred. There was no evidence of reaction in the upper portion of the alumina bed; instead it was found that bromine was adsorbed on the alumina. This experiment showed that $14 \mathrm{~g}$ of activated alumina would be needed as a disposal agent for $\mathrm{I} g$ of $\mathrm{BrF}_{5}$. However, the fact that the bromine is adsorbed on alumina rather than reacting with alumina suggests that activated alumina is unsuitable for use as a disposal agent.

Two experiments were performed to evaluate soda lime as a disposal agent. In one experiment the bed was $4 \mathrm{in.deep;} \mathrm{in} \mathrm{the} \mathrm{other} \mathrm{experiment} \mathrm{the}$ bed was approximately $6 \mathrm{in}$. deep. The $\mathrm{BrF}_{5}$ flow was $1.2 \mathrm{~g} / \mathrm{min}$ in a gas phase containing $50 \mathrm{v} / \mathrm{O} \mathrm{BrF}_{5}$ and $50 \mathrm{v} / 0$ nitrogen. Bromine was noted in the effluent-gas stream after 28 and $52 \mathrm{~g}$ of $B r F_{5}$ had been passed through the 4 -in. $(120-g)$ and 6 -in. $(220-g)$ beds, respectively. At this point in the reaction, the temperature of the upper portion of the soda lime bed was $100^{\circ} \mathrm{C}$ ** Just before bromine was noted in the effluent gas, water was observed in the effluent-gas stream. These experiments showed that about $4.3 \mathrm{~g}$ of soda lime is required per gram of $\mathrm{BrF}_{5}$ reacted. Examination of the soda lime bed after the reactions indicated that $B r F_{5}$ reacted completely with the soda lime. On the basis of these tests, soda lime appears to be a suitable disposal agent.

*In subsequent use of a large soda lime trap, a temperature of at least $100^{\circ} \mathrm{C}$ was necessary for the bromine to react with the soda lime. If the bed temperature is not raised to this value by the heat of the fluorine reaction, the disposal trap must be heated externally. 
IV. SUMMARY

A. Reactions with Simulated Fluid-bed Charges

The removal of uranium from simulated fluid-bed charges containing either $\mathrm{UF}_{4}$ and $\mathrm{UO}_{2} \mathrm{~F}_{2}$ or $\mathrm{U}_{3} \mathrm{O}_{8}$ and alumina and cold fission products was essentially complete after reaction times of $1-2 \mathrm{hr}$ at $350-400^{\circ} \mathrm{C}$ using about $20 \mathrm{v} / 0 \mathrm{BrF}_{5}$ in nitrogen as the fluorinating gas. The addition of Zircaloy decladding product or stainless steel decladding product did not hinder the removal of uranium. Plutonium, added to these mixtures as $\mathrm{PuO}_{2}$, was not volatilized during the $\mathrm{BrF}_{5}$ fluorination, but appeared to be quantitatively converted to $\mathrm{PuF}_{4}$. In a fluorination with fluorine at $500-550^{\circ} \mathrm{C}$ following the $\mathrm{BrF}_{5}$ step, the plutonium was satisfactorily converted to $\mathrm{PuF}_{6}$ in a reaction time of about $8 \mathrm{hr}$.

B. Kinetics of the Reaction of $\mathrm{BrF}_{5}$ with $\mathrm{UF}_{4}, \mathrm{UO}_{2} \mathrm{~F}_{2}, \mathrm{U}_{3} \mathrm{O}_{8}, \mathrm{UO}_{2}$, and $\mathrm{UO}_{3}$

The kinetics were measured in the range $200-360^{\circ} \mathrm{C}$ and in the $\mathrm{BrF}_{5}$ partial-pressure range of 74-369 Torr. Constants for the equations representing the combined temperature and pressure dependence of these reactions are listed in Table XIII. The activation energies derived from these equations are $16.9,8.3,9.2,7.5$, and $7.7 \mathrm{kcal} / \mathrm{mole}$ for the reactions with $\mathrm{UF}_{4}$, $\mathrm{UO}_{2} \mathrm{~F}_{2}, \mathrm{U}_{3} \mathrm{O}_{8}, \mathrm{UO}_{2}$, and $\mathrm{UO}_{3}$, respectively. Values of the coefficient $\mathrm{n}$ for the pressure term in the equation $k^{\prime}=A e^{-E} / R_{P^{n}}$ of $0.38,0.71,0.90$, 0.84 , and 1.05 were derived for the reactions with $\mathrm{UF}_{4}, \mathrm{UO}_{2} \mathrm{~F}_{2}, \mathrm{U}_{3} \mathrm{O}_{8}, \mathrm{UO}_{2}$, and $\mathrm{UO}_{3}$, respectively. The plots of Fig. 19 show the temperature dependence of the various reactions at a $\mathrm{BrF}_{5}$ partial pressure of 250 Torr.

TABLE XIII. Constants for Rate Equations for Reactions of $\mathrm{BrF}_{5}$ with Uranium Compounds Rate equation: ${ }^{a} \log \mathrm{k}^{\prime}=\mathrm{n} \log \mathrm{P}-\frac{\mathrm{A}}{\mathrm{T}}+\mathrm{B}$

\begin{tabular}{rrrrrr}
\hline & $\mathrm{UF}_{4}$ & $\mathrm{UO}_{2} \mathrm{~F}_{2}$ & $\mathrm{U}_{3} \mathrm{O}_{8}$ & $\mathrm{UO}_{2} \mathrm{~b}^{\mathrm{b}}$ & \multicolumn{1}{c}{$\mathrm{UO}_{3}$} \\
\hline $\mathrm{n}$ & 0.38 & 0.71 & 0.90 & 0.84 & 1.05 \\
$\mathrm{~A}$ & 3690 & 1810 & 2000 & 1630 & 1680 \\
$\mathrm{~B}$ & 4.286 & 0 & -0.220 & -0.270 & -0.767
\end{tabular}

Activation

Energy

\begin{tabular}{llllll} 
(kcal $/$ mole $)$ & 16.9 & 8.3 & 9.2 & 7.5 & 7.7 \\
\hline
\end{tabular}

${ }^{a} \mathrm{P}$ in Torr, $\mathrm{k}^{\prime}$ in $\mathrm{min}^{-1}, \mathrm{~T}$ in ${ }^{\circ} \mathrm{K}$.

$b_{\text {High reactivity } A N L ~} \mathrm{UO}_{2}$. 


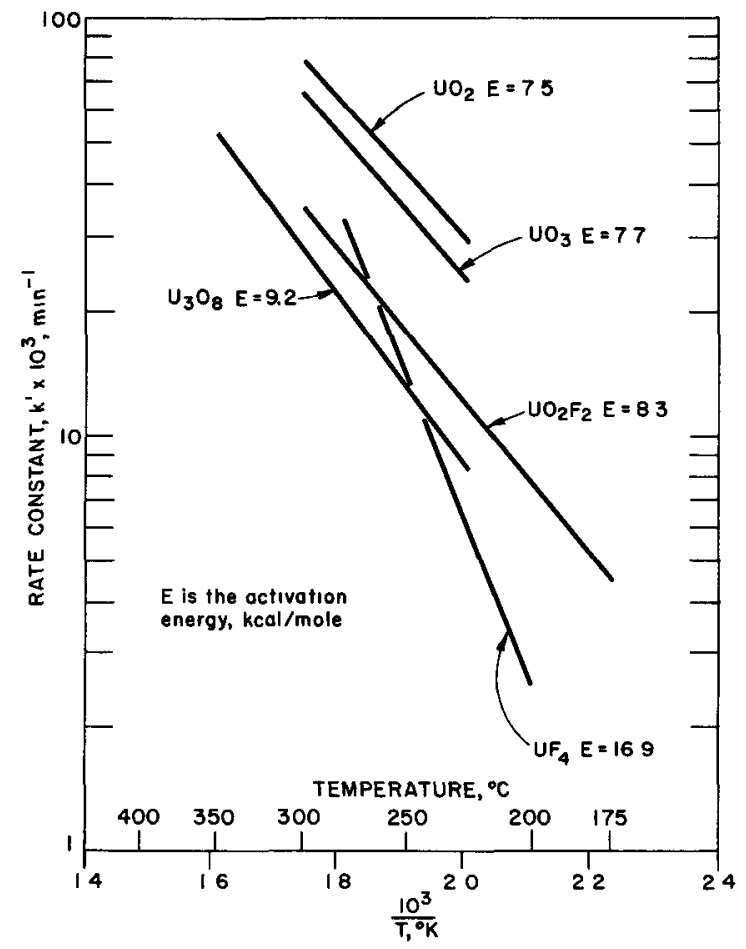

$308-401$

Fig. 19. Temperature Dependence of Rate Constants for Reactions of $\mathrm{BrF}_{5}$ with Uranium Compounds at a $\mathrm{BrF}_{5}$ Partial Pressure of 250 Torr
The reactions with $\mathrm{UF}_{4}$ and $\mathrm{UO}_{2} \mathrm{~F}_{2}$ did not involve the formation of an intermediate, but the reactions with $\mathrm{U}_{3} \mathrm{O}_{8}, \mathrm{UO}_{2}$, and $\mathrm{UO}_{3}$ involved the for mation of $\mathrm{UO}_{2} \mathrm{~F}_{2}$ either directly or by the reaction of product $U_{F}$ with the oxide.

C. Disposal of $\mathrm{BrF}_{5}$

Soda lime (a mixture of sodium hydroxide and calcium oxide containing about $10 \%$ water) was found to be a good agent for the disposal of $\mathrm{BrF}_{5}$. The reaction between soda lime and $\mathrm{BrF}_{5}$ results in the production of solid, nonvolatile reaction products, presumably mainly $\mathrm{NaF}$ and $\mathrm{NaBr}$. The tests showed that $4.3 \mathrm{~g}$ of soda lime is required to completely react $1 \mathrm{~g}$ of $\mathrm{BrF}_{5}$, and that a temperature of at least $100^{\circ} \mathrm{C}$ is necessary for efficient reaction of the bromine component in the upper portion of the soda lime trap.

\section{ACKNOW LEDGMENTS}

We thank R. C. Vogel and A. A. Jonke for their interest and support during the course of this investigation; $R$. P. Larsen and members of the Analytical Section for the many analyses they performed; R. V. Schblaske and his co-workers for X-ray diffraction analyses; and C. E. Johnson and N. M. Levitz of the Chemical Engineering Division and J. H. Handwerk of the Metallurgy Division for supplying several of the uranium compounds. 


\section{REFERENCES}

1. R. C. Voge1, M. Levenson, and F. R. Masten, Chemical Engineering Division Research Highlights, May 1964-April 1965, ANL-7020, pp. 100-101.

2. M. J. Steindler and F. Linzer, "Rate Studies on the Fluorination of Plutonium Tetrafluoride," Chemical Engineering Division Summary Report July, August, and September 1956, ANL-5633 (Dec 1956), pp. 27-30.

3. C. E. Johnson, J. Fischer, and M. J. Steindler, J. Am. Chem. Soc. 83, 1620 (1961).

4. I. Stein, J. Am. Chem. Soc. 81, 1273 (1959).

5. H. H. Claassen et al., J. Chem. Phys. 28, 285 (1958).

6. C. E. Johnson and J. Fischer, J. Phys. Chem. 65, 1849 (1961).

7. M. T. Rogers and J. L. Spiers, J. Phys. Chem. 60, 1462 (1956).

8. R. D. Long, The Liquid-Vapor Equilibria of the System Bromine Pentafluoride-Bromine Trifluoride, ANL-5405 (March 1955).

9. V. Y. Labaton, J. Inorg. Nuc1. Chem. 10, 86 (1959).

10. W. Davis, Jr. and R. L. Jarry, Reactions of Gaseous Chtorine Trifluoride with Uranium Tetrafluoride, Carbon and Carbon Chemicals Co., K-849 (Dec. 8, 1953).

11. H. Nguyen-Nghi, Compt. Rend. 256, 3465 (1953).

12. N. S. Nikolaev and Yn. D. Shishkov, Dokl. Akad. Nauk. SSSR 143, 130 (1962).

13. J. F. E1lis and C. W. Forrest, J. Inorg. Nuc1. Chem. 16, 150 (1960). See also J. J. Barghusen in Reactor Fuel Process. 7, 247 (1964); 8, 26 (1965).

14. R. C. Shrewsberry and E. L. Williamson, J. Inorg. Nucl. Chem. 28, 2535 (1966).

15. R. L. Jarry and W. Davis, Jr., Conversion of Uranium Compounds to Uranium Hexafluoride by Means of Chlorine Trifluoride. Part III. Fluorination of the Uranium Oxides at 60, 100, and $140^{\circ} \mathrm{C}$, Carbide and Carbon Chemicals Co. K-847 (Dec. 21, 1951).

16. M. Iwasaki and T. Sakurai, J. Nuc1. Sci. Technol. (Tokyo) 2, 225 (1965).

17. J. S. Anderson, Bul1. Soc. Chim. (France) 20, 781 (1953).

18. V. Y. Labaton and K. D. B. Johnson, J. Inorg. Nuc1. Chem. 10, 74 (1959).

19. I. Sheft, H. H. Hyman, and J. J. Katz, Anal. Chem. 25, 1877 (1953).

20. M. J. Steindler and D. V. Steid1, "Plutonium Fluoride Studies," Chemical Engineering Division Summary Report, April, May, and June 1958, ANL-5896 (Oct 1958), pp. 27-32.

21. M. Schmeisser and K. Brandle, Advances in Inorganic and Radiochemistry, Vo1. 5, Academic Press, New York, p. 70 (1960).

22. R. L. Harris, "Rate Studies of the Uranyl Fluoride-Chlorine Trifluoride Reaction," Paducah Plant Laboratory Quarterly Progress Report, JulySept 1964, KY-L-362 (Part 3), pp. 10-14, Union Carbide Corporation (Nov. 16, 1964). 
23. G. Vandenbussche and T. Kekendai, Compt. Rend. 256, 4657 (1963).

24. M. J. Steindler and D. Steidl, "Fluorination Rate of Uranyl Fluoride," Chemical Engineering Division Summary Report, October, November, and December 1958, ANL-5959 (1958), pp. 21-22.

25. M. Iwasaki, J. Inorg. Nuc1. Chem. 26, 1853 (1964).

26. G. A. Rampy, Fluorination of Recovery Oxide, Goodyear Atomic Corp., GAT-L-366 (June 5, 1957).

27. G. A. Rampy, The Reaction of Uranium Dioxide with Uranium Hexafluoride, Goodyear Atomic Corp., GAT-265 (June 5, 1959). 